Review

\title{
Zebrafish Model in Ophthalmology to Study Disease Mechanism and Drug Discovery
}

\author{
Yiwen Hong and Yan Luo * \\ State Key Laboratory of Ophthalmology, Zhongshan Ophthalmic Center, Sun Yat-Sen University, \\ Guangzhou 510060, China; hongyw@mail2.sysu.edu.cn \\ * Correspondence: luoyan2@mail.sysu.edu.cn; Tel.: +86-020-87335931
}

check for updates

Citation: Hong, Y.; Luo, Y. Zebrafish Model in Ophthalmology to Study Disease Mechanism and Drug Discovery. Pharmaceuticals 2021, 14, 716. https://doi.org/10.3390/ ph14080716

Academic Editors: Yuhei Nishimura and Martin Distel

Received: 9 June 2021

Accepted: 21 July 2021

Published: 25 July 2021

Publisher's Note: MDPI stays neutral with regard to jurisdictional claims in published maps and institutional affiliations.

Copyright: (c) 2021 by the authors. Licensee MDPI, Basel, Switzerland. This article is an open access article distributed under the terms and conditions of the Creative Commons Attribution (CC BY) license (https:// creativecommons.org/licenses/by/ $4.0 /)$.

\begin{abstract}
Visual impairment and blindness are common and seriously affect people's work and quality of life in the world. Therefore, the effective therapies for eye diseases are of high priority. Zebrafish (Danio rerio) is an alternative vertebrate model as a useful tool for the mechanism elucidation and drug discovery of various eye disorders, such as cataracts, glaucoma, diabetic retinopathy, age-related macular degeneration, photoreceptor degeneration, etc. The genetic and embryonic accessibility of zebrafish in combination with a behavioral assessment of visual function has made it a very popular model in ophthalmology. Zebrafish has also been widely used in ocular drug discovery, such as the screening of new anti-angiogenic compounds or neuroprotective drugs, and the oculotoxicity test. In this review, we summarized the applications of zebrafish as the models of eye disorders to study disease mechanism and investigate novel drug treatments.
\end{abstract}

Keywords: zebrafish; eye; disease model; mechanism; drug candidate

\section{Introduction}

Until 2020, an estimated 295 million people suffer from the moderate and severe visual impairment worldwide, and among them, about 43.3 million people are even blind [1] The leading global causes of blindness are cataract, followed by glaucoma, age-related macular degeneration (AMD), and diabetic retinopathy (DR) [2]. Visual impairment is a major concern of public health worldwide. The understanding of the pathological mechanisms involved in eye diseases is quite vital for the development of new therapeutics. Similarly, the available animal models characterized by closely mimicking eye pathology and allowing medium-throughput drug screening are desirable. Hence, model organisms with similar physiology to humans are essential to understand the developmental processes, identify potentially causative genes and factors for human eye disorders and develop the novel drug treatments [3].

Zebrafish (Danio rerio) is a kind of common aquarium fish originating from India and has become a prominent vertebrate model for studying diseases $[4,5]$. Zebrafish is more phylogenetically distant from humans than rodent, but it has $82 \%$ orthologues of human disease-associated genes [5]. In addition, zebrafish has a short generation time of 2-4 months, is productive with a single mating pair producing around 200 offspring at weekly intervals, and is easy to maintain at a low cost [6]. Importantly, the transparent zebrafish embryo develops ex utero, making the visualization of early organogenesis possible. The zebrafish eyes are relatively large compared to its overall small-size body, which enables eye bud manipulation during the early embryogenesis. Therefore, the easy accessibility of genes and embryos in zebrafish, as well as the similarity of eye with humans, has made zebrafish a predominant model of different eye diseases to elucidate their mechanism and investigate new treatments.

In this review, we highlighted the use of zebrafish in modeling eye diseases by (i) introducing the characteristic anatomy and development of zebrafish eye, (ii) summarizing zebrafish models of eye diseases, such as cornea dystrophy, cataract, glaucoma, ocular 
vascular diseases, and photoreceptor degeneration, and (iii) presenting contributions of these models in the investigation of new drug candidates for eye diseases.

\section{Anatomy and Development of Zebrafish Eye}

Although zebrafish eyes are very small compared with those of humans, they contain almost all the basic structures of human eyes. Firstly, we focused on the anatomy and development of the zebrafish eye to explain why zebrafish is a promising model for human eye diseases.

\subsection{Anatomy of Zebrafish Eye}

\subsubsection{Cornea}

Both of the zebrafish and human cornea contain five major layers: the epithelium, Bowman's layer, stroma, Descemet's membrane, and endothelium. In its mature state, the zebrafish corneal epithelium is $12.5 \mu \mathrm{m}$ thick with four to six cell layers. The stroma is approximately $6 \mu \mathrm{m}$ thick with 34 to 40 layers [7]. The endothelium, Bowman's layer, and Descemet's membrane are well developed. Several polypeptides highly enriched in the epithelium or the stroma of zebrafish cornea are the excellent markers of corneal differentiation [7]. Despite the similarities, the zebrafish ocular surface is dramatically different from the human, such as the absence of corneal nerve fibers, the thinner stroma, and the presence of rodlet cells [8].

\subsubsection{Iridocorneal Angle}

Iridocorneal angle, the region where the cornea meets the iris, hosts cells specialized in maintaining intraocular pressure (IOP) [9]. IOP is balanced by the production and drainage of aqueous humor. Although the zebrafish ciliary epithelium lacks folds and processes, it still produces aqueous humor [9]. The servo-null electrophysiology is used to measure IOP in the anesthetized adult zebrafish as follows: when a pulled-glass microelectrode penetrates the cornea into the anterior chamber, the pressure transduction can be recorded [10]. Although the trabecular meshwork and aqueous humor dynamics of zebrafish are quite different from those of humans, the overall similarities in the average IOP and outflow tissue structure of aqueous humor make zebrafish a great model to investigate the complicated genetics of human glaucoma.

\subsubsection{Lens}

Almost all the morphological features of human lens can be observed in the zebrafish eye [9]. The fish lens is more spherical than the human lens, and it is made up of an outer epithelial layer covering the elongated fiber cells [11]. Most lens epithelial cells are quiescent, except for a band of cells encircling the marginal equator, which finally proliferate and differentiate into fiber cells. Lens fiber cell differentiation happens in the transition zone, where elongating fiber cells lose their internal organelles and aid in the transparency [12]. In both the human and zebrafish, three kinds of lens crystallins are found: $\alpha, \beta$, and $\gamma$. The similarities with human lenses make zebrafish an excellent model for studying crystallins in a living animal using the live embryo imaging.

\subsubsection{Visual System}

Zebrafish is visually responsive at $72 \mathrm{~h}$ post fertilization (hpf), when the retina mirrors adult human retinal morphology and function [7]. Zebrafish retina is made up of an outer nuclear layer (ONL), outer plexiform layer (OPL), inner nuclear layer (INL), inner plexiform layer (IPL), and ganglion cell layer (GCL). It also possesses the same broad classes of retinal neurons in humans, such as retinal ganglion cells (RGC), bipolar cells, horizontal cells, and amacrine cells, and the same glial elements including Müller cells, astrocytes, and microglia (Figure 1) [6,13]. Furthermore, the zebrafish retina is cone-rich and analogous to the human macula, which results in good color vision and high-acuity vision [13]. In addition, zebrafish has four types of cones: blue (sws2), ultraviolet (sws1), 
green ( $r h 2)$, and red (lws), among which the green and red cones exist as a physically fused double cones [13,14]. Visual signals arising from the photoreceptors are transmitted through the whole retina to the ganglion cells and subsequently transferred to the brain [3].
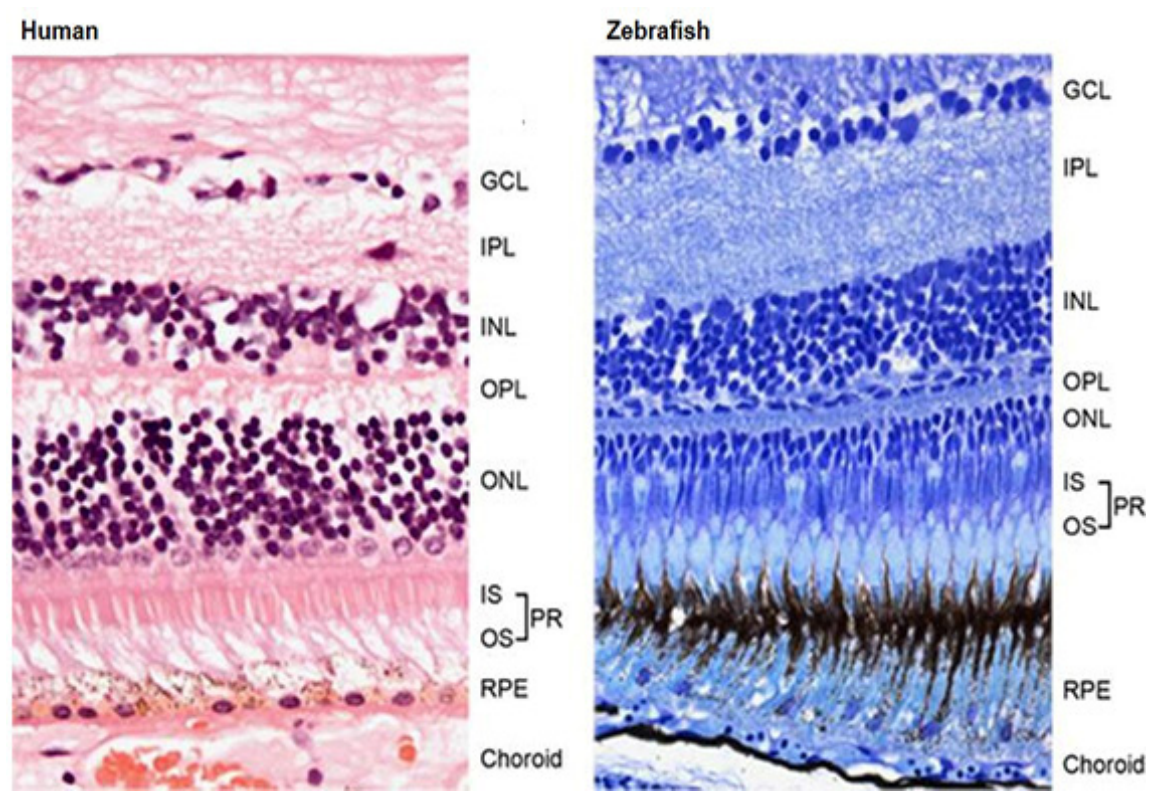

Figure 1. Cross-sectional view of the human and zebrafish retina indicating the similar structural features of the retinal layers [6].

Zebrafish visual acuity is typically measured using the behavioral tests, including optokinetic response and optomotor response. The optokinetic response is a robust behavior in which moving objects evoke the tracking eye movements [15]. It is one of the most widely studied behaviors, due to its reliability and performance even in the immobilized larvae. Additionally, the optomotor response is a robust visual response in larval zebrafish, which is mediated by the red/green cone pathway [16]. When presented with a whole field moving stimulus, fish will turn and swim in the direction of perceived motion. Larvae can perform this behavior when swimming freely or when restrained by embedding their head in agar.

\subsubsection{Vasculature System}

The basic vascular biology of the developing zebrafish embryo is analogous to that of other vertebrates, and angiogenesis also plays a vital role in the zebrafish hyaloid vessel, which is similar to the development of retinal vasculature in mammalian embryos $[17,18]$. The primary zebrafish retinal vasculature branches from the central retinal artery by angiogenesis between 24 and $29 \mathrm{hpf}$. The optic artery goes into eye in a ventral direction through the optic fissure and forms a hyaloid loop, which exits the choroid fissure as the hyaloid vessel [6]. After passing through the choroid fissure, this artery system forms a network on the lens before 5 days post fertilization (dpf) $[17,19]$. The hyaloid vessels branch and adhere to the inner limiting membrane of the juvenile retina by $30 \mathrm{dpf}$, unlike the regression observed in humans [19-21]. Knockdown of some genes encoding crucial proteins involved in angiogenesis, such as cldnh, can interrupt the lumenization of the hyaloid vessels (Figure 2) [22]. Recently, new imaging techniques such as in situ hybridization for vascular-specific genes, dye injection-based vessel visualization, and the functional manipulation of vasculature in zebrafish embryos make zebrafish an exciting model for investigating human ocular vascular diseases [18]. In addition, more and more transgenic lines expressing fluorescent reporter proteins in the vascular system have emerged to help to study vascular diseases, such as the $\mathrm{Tg}$ (fli1: EGFP) line, which expresses EGFP under the control of fli1 regulatory sequences [22-24]. 


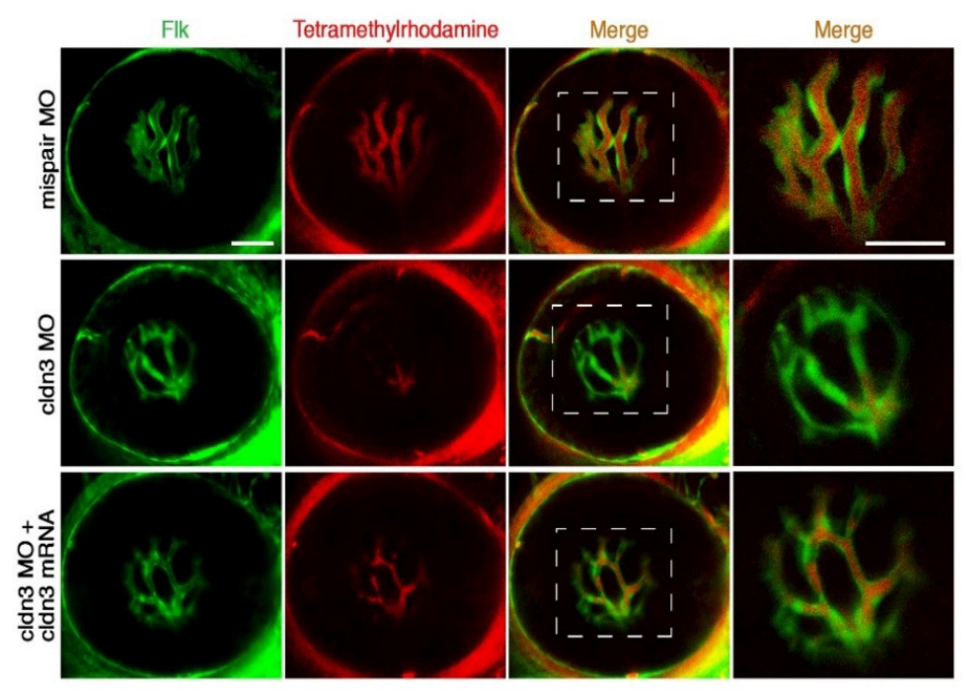

Figure 2. Lumen formation analyses of the hyaloid vessels in the $5 \mathrm{dpf}$ zebrafish. More severe filling defects (more non-perfusion areas) of hyaloid vessels were observed in the cldnh MOs-injected zebrafish as compared to the mispair MO-injected or the cldnh mRNA-rescued zebrafish, indicating lumenization defects of the hyaloid vessels in the cldnh knockdown group. Scale bar: $50 \mu \mathrm{m}$ [22].

\subsection{Development of Zebrafish Eye}

The development of zebrafish eye is strongly similar with that of humans and other vertebrates $[25,26]$. They all develop from three distinct embryological layers: surface ectoderm forming the lens and subsequently the corneal epithelia; neuroectoderm forming the neural retina, retinal pigment epithelium (RPE), optic stalk, and ciliary body; and neural crest cell-originated mesenchyme forming the corneal endothelium and stroma, iris stroma, vasculature, and sclera. Here, we drafted a schematic diagram indicating the development of zebrafish eye according to some studies in the literature (Figure 3) [6,9].

A

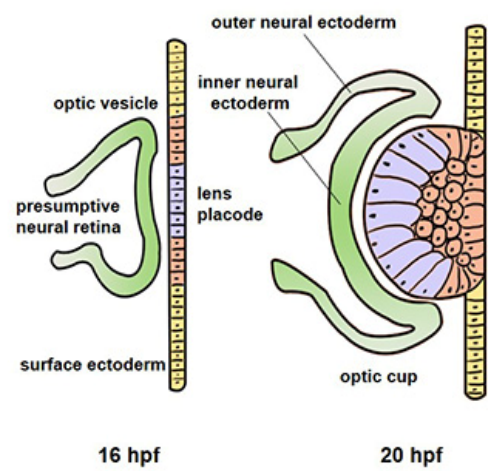

B

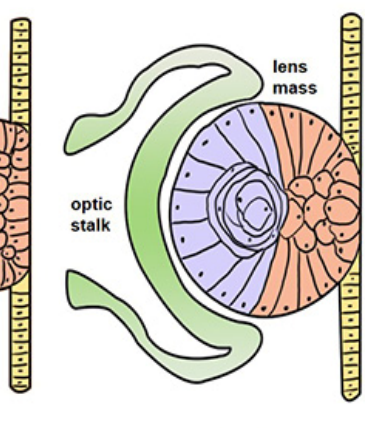

$22 \mathrm{hpf}$
D

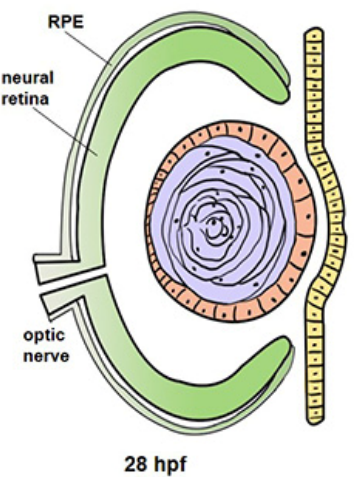

Figure 3. Schematic diagram indicating the development of zebrafish eye. The optic vesicle and lens placode are formed as the central eye field splits at $16 \mathrm{hpf}(\mathbf{A})$. The distal portion of the optic vesicle invaginates so that a double-walled cup structure composed of an inner and outer neural ectoderm can be seen by $20 \mathrm{hpf}$ (B). The optic cup grows circumferentially. The lens placode gives rise to a solid lens mass due to progressive delamination of the surface ectoderm cells by $22 \mathrm{hpf}(\mathbf{C})$. The inner layer of the optic cup gives rise to the neural retina, while the outer layer differentiates into the RPE by $28 \mathrm{hpf}$ (D). Finally, cells of the central lens placode move to the posterior lens mass and give rise to primary lens fiber cells (purple); cells of the peripheral lens placode migrate to the anterior lens mass to form the anterior epithelium (orange); the cornea (yellow) develops when the lens placode closes after the lens mass, taking apart from the surface ectoderm.

The development of zebrafish eye is fairly rapid. Neurogenesis begins at $28 \mathrm{hpf}$, and zebrafish embryos possess visual function as early as $72 \mathrm{hpf}[27,28]$. The optic vesicle, 
which finally gives rise to the neural retina and the RPE, evaginates from the forebrain at around $12 \mathrm{hpf}$ and remains attached to the forebrain through a transient structure called the optic stalk [3]. After a series of morphogenetic events, the optic vesicle gives rise to the optic cup at 16 to $20 \mathrm{hpf}$, forms ventrally the optic fissure by $24 \mathrm{hpf}$, and later closes by $48 \mathrm{hpf}$ [29]. The lens placode delaminates from the surface ectoderm cells overlying the optic cups at $16 \mathrm{hpf}[6,30]$, forms a solid lens mass at approximately $24 \mathrm{hpf}$, and fully detaches from the surface ectoderm by the apoptosis of the intervening cells by $28 \mathrm{hpf}[11,31,32]$. At $30 \mathrm{hpf}$, the surface ectoderm that does not form the lens begins to possess corneal epithelial identity, and it forms migratory periocular mesenchymal cells migrating into the cornea from the peripheral regions of the optic cup between 30 and $36 \mathrm{hpf}[7,33]$.

\section{Zebrafish as a Model for Studying Mechanisms of Eye Disorders}

With genetic accessibility, similar characteristics of human ocular development and easy controllability of living environment zebrafish has been used as a popular model to study eye disorders. Over the past decades, many human ocular diseases, such as cataract, glaucoma, DR, and AMD, have already been modeled in zebrafish. Here, we briefly introduced some important zebrafish models of eye diseases from anterior segments to posterior segments.

\subsection{Corneal Dystrophy}

Corneal dystrophies have a variable age of onset, variable inheritance, and progressive effects on corneal transparency and vision [34]. Due to the thinner stroma and presence of rodlet cells in the zebrafish cornea, zebrafish is seldom utilized to study the normal or pathological human corneas. Meanwhile, zebrafish has been used to study the function of genes whose mutation cause corneal dystrophy due to its genetic accessibility. Some genes responsible for human corneal dystrophy, such as pip $5 k 3$, col17a1, and keratocan, also express in the zebrafish cornea. pip $5 \mathrm{k} 3$ and col17a1 are quite conservative without ocular alteration, while keratocane is significant for corneal transparency and structure [35-37]. Likewise, the loss of lama1, a gene encoding an important basal membrane protein, leads to focal corneal dysplasia in zebrafish [38]. Overall, probably due to some structural difference from humans, only four of the genes mentioned above have been reported to study corneal dystrophy in zebrafish models, which is quite few compared with mouse models [8]. Therefore, the use of zebrafish to study human corneal diseases should be undertaken with some particular caution.

\subsection{Cataract}

Cataract, which is characterized by cloudy vision due to lens opacity, mainly includes congenital cataract and age-related cataract (ARC). Genetic studies have identified over 30 causative mutation genes for congenital or other early-onset forms of cataract and only few ARC-associated gene variants [39]. Nevertheless, the causative genes for many cases of cataract remain unidentified. When causative genes of human cataract are knocked down in zebrafish embryos, cataract or other lens abnormalities are often present (Table 1). Therefore, zebrafish is a promising animal model to reveal the specific mechanism involved in cataract formation.

The use of zebrafish cataract model mainly focuses on the congenital cataract. Among the known gene mutations caused cataracts, mutations in lens crystallins account for the majority, followed by mutations in various growth or transcription factors, connexins, membrane proteins, and lipid metabolism [40]. Hence, the mechanism of crystalline in cataract formation has been deeply investigated. Recently, scientists have identified the function of a cataract-causing gene using the zebrafish model. Mutation of the $C R Y A B$ gene, a member of $\alpha$-crystalline, results in congenital cataract by activating glucocorticoid receptor signaling [41]. Similarly, the cloche mutant in zebrafish displays cataract related to the insolubility of $\gamma$-crystalline and the faulty differentiation of lens fiber cells [42]. Meanwhile, the cataract phenotype can be rescued by the overexpression of $\alpha A$-crystalline in the cloche mutant. 
Therefore, the cloche mutation can be used to investigate the aggregation of lens crystallin and prevent cataract. In addition, the overexpression of Pax6, which is a paired box and homeobox domain protein expressing in the developing nervous system and eye, causes defects in lens fiber cells and human congenital cataract. The Pax6 mutant in zebrafish shows the alterations in the eye size and the abnormalities in lens differentiation $[39,43,44]$. The mutation of Pitx 3 and Foxe3 genes can cause the mesenchymal dysgenesis of anterior segment and cataracts in humans, and the knockdown of Pitx3 and Foxe3 in zebrafish via antisense morpholino results in the lens dysmorphogenesis [45-49]. Interestingly, the mutations in Hsf4, a member of the heat-shock transcription factor family, lead to isolated cataracts in humans and an early onset cataract with multiple developmental defects in zebrafish lens by interrupting the terminal differentiation of a lens fiber cell $[40,50]$.

$\mathrm{ARC}$ also has a genetic component, which makes individuals with the variation more vulnerable to environmental insults and aging [51]. Since the very old, even 2.5-year-old, zebrafish lens is not cloudy at all, zebrafish is not a predominant organism for modeling ARC [52]. However, zebrafish is a wonderful tool to investigate the mechanisms of crystalline-involved ARC. The chaperone capacity of $\alpha$-crystallins is considered to be titrated out by the binding of the damaged lens proteins as well as the truncation and insolubilization of the small heat shock proteins; so zebrafish is used to establish a link between in vitro mechanistic models of $\alpha$-crystallin chaperone and their roles in lens aging $[53,54]$. Additionally, mutation in the CRYGC gene ( $\gamma$ C-crystalline) causes a remarkable reduction in the thermal stability of $\gamma C$-crystalline and raises the risk of lens opacity when exposed to heat and UV-irradiation stresses, finally resulting in cataract [55].

Table 1. Genetic mutations of zebrafish models for congenital cataract.

\begin{tabular}{|c|c|c|c|}
\hline Function & Mutant Gene & Ocular Phenotype & Reference \\
\hline \multirow{4}{*}{$\begin{array}{l}\text { encoding } \\
\text { crystallins }\end{array}$} & $C R Y A A(\alpha A$-crystallin $)$ & $\begin{array}{c}\text { crystal-like opacity sporadically spreading across the lens, or frequent } \\
\text { droplets covering a large fraction of the lens }\end{array}$ & {$[54]$} \\
\hline & $C R Y A B(\alpha B$-crystallin $)$ & same as CRYAA & {$[41]$} \\
\hline & $C R Y G C(\gamma C$-crystalline $)$ & same as $C R Y A A$ & [55] \\
\hline & CRYGD $(\gamma D$-crystallin $)$ & same as CRYAA & [56] \\
\hline \multirow{5}{*}{$\begin{array}{c}\text { encoding } \\
\text { developmental } \\
\text { factors }\end{array}$} & DNase1l1l & retaining nuclei in lens fiber cells & [57] \\
\hline & epha2 & smaller eye, lens opacification and coloboma & [58] \\
\hline & mab21l2 & $\begin{array}{c}\text { microphthalmia, colobomas, small and disorganized lenses, } \\
\text { cornea dysgenesis }\end{array}$ & [33] \\
\hline & plod3 & $\begin{array}{l}\text { distorted and dislocated lenses from an early stage dislocated, lack of } \\
\text { normal lens capsule }\end{array}$ & [59] \\
\hline & $r b m 24$ & coarse and irregular lens, small-size retina and lens & {$[60]$} \\
\hline \multirow{4}{*}{$\begin{array}{l}\text { encoding } \\
\text { membrane } \\
\text { proteins }\end{array}$} & aqp $0 a$ & $\begin{array}{l}\text { nuclear opacity and widespread cortical fiber-to-fiber membrane } \\
\text { stacking defects }\end{array}$ & [61] \\
\hline & gja8 & various sizes of lens opacity & {$[62]$} \\
\hline & kpna4 & rugged and cloudy center part of the lens & [63] \\
\hline & pgrmc1 & $\begin{array}{l}\text { minor or mild nuclear central mass with fiber cell disorganization, and } \\
\text { moderate or severe nuclear density with pitting }\end{array}$ & {$[64]$} \\
\hline \multirow{4}{*}{$\begin{array}{l}\text { encoding } \\
\text { transcription } \\
\text { factors }\end{array}$} & celf1 & lens defects and cataract & [65] \\
\hline & foxe3 & smaller eye and small, deformed or absent lenses & [49] \\
\hline & hsf4 & $\begin{array}{l}\text { cataract with overproliferation of the lens epithelial cells and excessive } \\
\text { accumulation of fiber cells }\end{array}$ & [50] \\
\hline & pitx3 & $\begin{array}{c}\text { severe lens degeneration, lack of anterior chambers and outer } \\
\text { segment structures }\end{array}$ & [45] \\
\hline
\end{tabular}




\subsection{Glaucoma}

Glaucoma is a kind of optic neuropathy characterized by the progressive and irreversible visual field loss and visual impairment secondary to RGC loss [66]. Primary open angle glaucoma (POAG) without a certain physical cause explains $75-90 \%$ of glaucoma and possesses RGC loss, which is the common hallmark of other glaucoma phenotypes [67]. Other forms of glaucoma have also been classified, including primary closed angle glaucoma (POCG), developmental glaucoma, pigmentary glaucoma, steroid-induced glaucoma, etc $[10,68,69]$.

Zebrafish offer great chances to test specific hypotheses associated with glaucoma [9]. For instance, zebrafish have been utilized to demonstrate that SIX6 variants interrupt the development of the neural retina and result in a decreased number of RGC and an increased risk of glaucoma-associated visual impairment [70-72]. As another instance, zebrafish has been used to study the function of FOXC1, which is one of the few well-established genes related to POAG [73]. The transcription factor FOXC1 has been found as a vital mediator that reacts to oxidative pressure and suppresses apoptosis in cells associated with aqueous humor dynamics [74,75]. Furthermore, the Bugeye mutant, which develops high IOP, enlarged eye globes, morphological abnormalities, and functional deficits in the retina, is identified as the model for myopia and glaucoma [76,77]. Many zebrafish models for glaucoma have been recently established based on human glaucoma (Table 2). However, all the mutations mentioned above do not relate to POCG, which is possibly because POCG is a complex heterogeneous disease that cannot be modeled by a single gene mutation.

Neurodegeneration in the form of RGC death is well documented in glaucoma. The chemical or oxidative stress-induced retinal damage is related to RGC injury and used in zebrafish research [28]. For example, NMDA, an analog of L-glutamate and an excitatory neurotransmitter in the mammalian central nervous system, can induce cellular excitotoxicity and RGC loss, and then glaucoma and retinal neurodegeneration [78]. However, the NMDA-induced neurotoxicity model only focuses on a sole mechanism of glutamate excitotoxicity in glaucoma pathology. Since the pathogenesis of glaucoma in humans is more complicated, this model may not thoroughly demonstrate the disease process, but the NMDA injection is a feasible choice for normal-tension glaucoma [79]. Additionally, oxidative injury plays an essential role in glaucoma onset as well as an imbalance between pro-oxidant and antioxidant capacities [80]. Therefore, the intravitreal injection of hydrogen peroxide in $5 \mathrm{dpf}$ zebrafish larvae is used to establish the glaucoma model [81]. Nevertheless, a major flaw of utilizing zebrafish to study glaucoma is the notable capacity for retinal cell regeneration, including the GCL [81,82]. In summary, the zebrafish models of glaucoma chiefly shed light on POAG associated with gene mutation, and on RGC injury. 
Table 2. Zebrafish models of glaucoma.

\begin{tabular}{|c|c|c|c|c|}
\hline Method & $\begin{array}{c}\text { Injury } \\
\text { Paradigm }\end{array}$ & Ocular Phenotype & Model & Reference \\
\hline \multirow{11}{*}{$\begin{array}{l}\text { Gene- } \\
\text { Targeted }\end{array}$} & cpamd8 & Iridocorneal angle hypoplasia & POAG & [83] \\
\hline & cyp1b1 & $\begin{array}{l}\text { Neural crest migration into the } \\
\text { anterior segment }\end{array}$ & POAG & {$[84]$} \\
\hline & foxc1 & RGC loss & POAG & [85] \\
\hline & gpatch3 & $\begin{array}{l}\text { Anterior chamber angle hypoplasia } \\
\text { and a decreased number of iridophores }\end{array}$ & POAG & [86] \\
\hline & gucalc & RGC apoptosis & POAG & [87] \\
\hline & ocrl & $\begin{array}{l}\text { Defective cilia formation in } \\
\text { Kupffer vesicles }\end{array}$ & POAG & {$[88]$} \\
\hline & pitx2 & $\begin{array}{l}\text { Abnormal development of the cornea, } \\
\text { iris, and iridocorneal angle }\end{array}$ & POAG & [89] \\
\hline & pmel & $\begin{array}{c}\text { Profound pigmentation defects and } \\
\text { enlarged anterior segments }\end{array}$ & $\begin{array}{l}\text { Pigmentary } \\
\text { glaucoma }\end{array}$ & [90] \\
\hline & $\operatorname{six} 6$ & $\begin{array}{l}\text { Smaller eyes and reduced number } \\
\text { of RGC }\end{array}$ & POAG & {$[70]$} \\
\hline & Tg (Bugeye) & $\begin{array}{l}\text { Decreased retinal cell densities and } \\
\text { diminished outer retinal function }\end{array}$ & POAG & [91] \\
\hline & $w d r 36$ & Thinner retinal layers and smaller eyes & POAG & [92] \\
\hline $\begin{array}{l}\text { Chemical- } \\
\text { Induced }\end{array}$ & $\begin{array}{l}\text { N-Methyl-D- } \\
\text { aspartic acid } \\
\text { (NMDA) }\end{array}$ & RGC loss & Glaucoma & [78] \\
\hline $\begin{array}{l}\text { Oxidative } \\
\text { Stress- } \\
\text { Induced }\end{array}$ & $\begin{array}{l}\text { hydrogen } \\
\text { peroxide }\end{array}$ & RGC injury & Glaucoma & [81] \\
\hline
\end{tabular}

\subsection{Vascular Disease}

Pathological retinal angiogenesis makes a great contribution to irreversible causes of visual impairment at all ages, such as retinopathy of prematurity (ROP), DR, and AMD. Due to the significant similarities of vasculature between zebrafish and human, zebrafish embryos have been used for the identification of genes and mechanisms involved in pathological retinal angiogenesis.

\subsubsection{Diabetic Retinopathy}

The crude prevalence of blindness caused by DR shows a global increase in agestandardized prevalence in 2020 [2]. DR is a common microvascular complication of diabetes, with manifestations of vision loss or blindness caused by the damage to retinal blood vessels. Animal models, such as mouse models and rat models, have been used to investigate the pathogenesis of DR and discover novel drugs. There is a rising interest in the DR zebrafish model due to their similar retinal vascular pathology and glucose metabolism as humans [93].

Retinal abnormalities of hyperglycemic zebrafish are consistent with those of diabetic patients. After being immersed alternately in glucose solution and water for 28 days, zebrafish has a remarkably thinner IPL and INL [94]. Moreover, hyperglycemia influences the cone photoreceptor neuron layer [95]. Further study shows that zebrafish retinal electrophysiology is adversely affected by the prolonged hyperglycemia, with separate actions in both distal and proximal retina [96]. Additionally, a recent study describes a novel, short-term, in vivo screening method for compounds affecting DR by exposing adult zebrafish to hyperglycemia conditions [97]. After treating with $130 \mathrm{mM}$ glucose from 3 to $6 \mathrm{dpf}$, the zebrafish embryos show the dilation of hyaloid-retinal vessels as well as 
the increased levels of vascular endothelial growth factor (VEGF) at $6 \mathrm{dpf}$ [97]. The $p d x 1$ mutants in zebrafish provide the only known model in which hyperglycemia-induced retinal angiogenesis can be studied [98]. Therefore, these zebrafish models have a realistic prospect in screening new drug candidates for DR treatment $[99,100]$.

\subsubsection{Retinopathy of Prematurity}

ROP is a kind of retinal vasoproliferative disease in premature infants and one of the leading causes of childhood blindness [101]. As ROP is a developmental disease, the zebrafish embryos can be a potential model for rapidly evaluating pharmaceutical treatments with a huge sample size in a short time span [102]. The zebrafish ROP model is established as follows: treating the $\operatorname{Tg}(f l i 1: E G F P)$ zebrafish with a hypoxia-inducing agent, followed by GS4012 (a VEFG inducer) at $24 \mathrm{hpf}$; then, the number of sprouts and vascular branches dramatically grow in the central retinal vascular trunks [102]. In addition, exposed to 10\% air-saturated water for 3-12 days, adult $\operatorname{Tg}$ (fli1:EGFP) zebrafish can also develop severe retinal vascular proliferation [103].

\subsubsection{Age-Related Macular Degeneration}

AMD, which blur the central vision, is a disorder with multifactorial pathogenesis, including angiogenesis, dysregulation in the complement, lipid, inflammatory, and extracellular matrix pathways [2,104]. Neovascular AMD, the subtype responsible for most of the vision loss, is characterized by the choroidal neovascularization in the macular area. The hypoxia-induced retinopathy model in mature zebrafish can be used to investigate neovascular AMD [103]. Similarly, the inactivation of the von Hippel-Lindau (VHL) gene promotes hypoxia-inducible factor signaling and consequent VEGF expression [18]. Accordingly, severe neovascularization of the choroid and hyaloid vessels, as well as retinal detachment and macular edema, have been noted in the VHL knockout zebrafish embryos [105]. Hence, VHL mutant zebrafish can be a model for neovascular AMD.

Dry AMD, the subtype characterized by RPE disorder, can result in the loss of photoreceptor cells. Interestingly, the zebrafish with the gnn mutant displays the AMD-related degeneration of red cones at around $5 \mathrm{dpf}$ [106]. Additionally, the overexpression of HTRA1, a protein involved in the pathophysiology of AMD, can induce an accumulation of lipofuscin and melanolipofuscin between the photoreceptor and RPE layers in zebrafish [28]. The transgenic overexpression of human HTRA1 in zebrafish displays certain morphologic changes of the RPE, photoreceptor cell death, and lipofuscin accumulation, which are the features of early AMD [107]. Recently, the RP1L1 mutant zebrafish using CRISPR/Cas9 genome editing is the first zebrafish model of photoreceptor degeneration with subretinal drusen deposits, which is a hallmark of AMD [108].

\subsection{Photoreceptor Degeneration}

Photoreceptor degeneration diseases are exceedingly various, creating the challenges of preventing or reversing vision loss. Due to the similarities in retinal anatomy and function between zebrafish and humans, the zebrafish model has become a predominant model for studying the photoreceptor development and disease. Here, we focused on retinitis pigmentosa (RP) and Leber congenital amaurosis (LCA), which are two major kinds of retinal degeneration diseases [109].

\subsubsection{Retinitis Pigmentosa}

$\mathrm{RP}$ is a disease characterized by decreased night vision and loss of peripheral vision due to the progressive photoreceptor cell death and dysfunction of the photoreceptors. The most common cause of human autosomal RP is the mutation in the rod-specific opsin gene, rhodopsin (RHO). Recently, various $R H O$ mutant zebrafish models associated with dominant or recessive RP have been established with progressive rod degeneration [110-112]. Importantly, cone photoreceptors in zebrafish are unaffected by RHO mutants, which is consistent with the features of human RP caused by the RHO mutation $[110,111]$. 
$\mathrm{X}$-linked RP, whose major cause is the mutation in retinitis pigmentosa $2(R P 2)$, is characterized by the early onset and rapidly progressive vision loss before 40 years old in humans [113]. Knockdown of RP2 in zebrafish results in a small eye phenotype, gradual loss of the photoreceptors' outer segments (OSs), and defective photoreceptor function, mimicking human X-linked RP [114,115]. Furthermore, zebrafish mutant phenotypes can be rescued by injecting human RP2 mRNA, revealing the vital role for $R P 2$ in the pathogenesis of X-linked RP [116]. Additionally, the great ability to simulate the various phenotypes of human RP in zebrafish models (Table 3) has been proved invaluable in identifying the causative genes for RP.

Table 3. Zebrafish models of retinitis pigmentosa-like diseases.

\begin{tabular}{|c|c|c|}
\hline Gene & Photoreceptor Features & Reference \\
\hline adipor1 & Decrease in rod photoreceptors & [117] \\
\hline cerkl & $\begin{array}{l}\text { Photoreceptor functional defects at } 7 \mathrm{dpf} \text {. Rod OS defects at } 3 \\
\text { months, cone OS defects at } 7 \text { months. Notable thinning of the } \\
\text { photoreceptor layer and cell death by } 12 \text { months }\end{array}$ & [118] \\
\hline dact2 & Photoreceptor disc membrane disarrangement at $5 \mathrm{dpf}$ & [119] \\
\hline eys & $\begin{array}{l}\text { Progressive photoreceptor loss; cone degeneration at } 6 \text { months, rod } \\
\text { degeneration at } 14 \text { months }\end{array}$ & [120] \\
\hline her9 & $\begin{array}{l}\text { Decrease in rod photoreceptors at } 5 \mathrm{dpf} \text {. Few double cones with } \\
\text { short OSs at } 12 \mathrm{dpf}\end{array}$ & {$[121]$} \\
\hline$k i f 3 b$ & Delayed OS development. Rapid rod degeneration by $5 \mathrm{dpf}$ & [122] \\
\hline myo7aa & Decreased photoreceptor function at $5 \mathrm{dpf}$. Reduced rods at $8 \mathrm{dpf}$ & [123] \\
\hline poc1 & Decrease length of photoreceptor OSs at $4 \mathrm{dpf}$ & [124] \\
\hline prom1 & $\begin{array}{c}\text { Decrease in cone photoreceptors at } 7 \mathrm{dpf} \text {. Longer rod Oss. Delayed } \\
\text { development of OSs }\end{array}$ & [125] \\
\hline $\operatorname{prpf31}$ & $\begin{array}{l}\text { Decreased in neuronal precursors and mature neurons at both } 48 \\
\text { and } 60 \mathrm{hpf}\end{array}$ & [126] \\
\hline rho & Rod loss observed at $6 \mathrm{dpf}$. Degeneration continues into adulthood & [112] \\
\hline$r p 1 l 1$ & $\begin{array}{l}\text { Rod dysfunction at } 6 \text { months. Subretinal drusenoid deposits at } 11 \\
\text { months. Photoreceptor loss at } 12 \text { months }\end{array}$ & [108] \\
\hline$r p 2$ & $\begin{array}{c}\text { Photoreceptor functional defects at } 7 \mathrm{dpf} \text {. Short rod OSs at } 2 \\
\text { months; cone OS defects at } 4 \text { months; significant rod OS loss and } \\
\text { decreased cone OSs by } 7 \text { months }\end{array}$ & [115] \\
\hline rpgrip1 & $\begin{array}{l}\text { No rod OSs at } 5 \mathrm{dpf} \text {. Cone dysfunction at } 7 \mathrm{dpf} \text {. Severe rod } \\
\text { degeneration by } 3 \text { months, followed by cone degeneration. } \\
\text { Degeneration of most photoreceptors by } 23 \text { months }\end{array}$ & [116] \\
\hline slc7a14 & $\begin{array}{l}\text { Decreased photoreceptor function at } 5 \mathrm{dpf} \text {. Reduced rod } \\
\text { photoreceptors and peripheral RPE at } 5 \mathrm{dpf}\end{array}$ & [127] \\
\hline SNRNP200 & Photoreceptors loss at $3 \mathrm{dpf}$ & [128] \\
\hline$u s h 2 a$ & $\begin{array}{l}\text { Decreased photoreceptor function at } 5-7 \mathrm{dpf} \text { and increased } \\
\text { photoreceptor apoptosis at } 8 \mathrm{dpf} \text {. Notable rod OS degeneration at } \\
12 \text { months, cone OS degeneration at } 20 \text { months }\end{array}$ & [129] \\
\hline
\end{tabular}

\subsubsection{Leber Congenital Amaurosis}

LCA is a kind of inherited retinal dystrophy disease responsible for early-onset childhood blindness with immense genetic heterogeneity [130]. Presently, there are at least 15 LCA-associated genes, including CEP290, RPE65, CRB1, KCNJ13, GUCY2D, AIPL1, CRX, IMPDH1, LCA5, LRAT, RPGRIP1, SPATA7, RD3, RDH12, and TULP1. CEP290 mutant zebrafish displays an intracellular transport delay and a decreased visual perception, which is analogous to human LCA patients [131]. Similarly, the knockout of LCA5 in zebrafish using 
CRISPR/Cas9 technology causes the impaired OS protein trafficking and then cone-rod dystrophy, which mimics the phenotype of cone-rod dystrophy in humans [132].

Mutation genes involved in ciliogenesis initiation and the transport of cilium components can result in LCA or an LCA-like phenotype in mouse models [133]. Intraflagellar transport proteins play vital roles in the movement of cargo in the cilium, which can be facilitated by kinesin motors [13]. For example, ift28, ift 88 , and ift172 mutants of zebrafish have the rapidly degenerated photoreceptors and without the developed photoreceptor OS [134-136]. The kif3a (kinesin family 3a) mutant in zebrafish causes photoreceptors to dramatically degenerate and fail to develop OSs, resulting in the extinguished ERG in zebrafish larvae $[122,137,138]$.

\section{Zebrafish as a Model for the Drug Discovery of Eye Disorders}

Since the drug candidates can be added to the water culture medium rather than injected into the fish, zebrafish has become a promising model for the various successful phenotype-based drug discovery $[5,139]$. Here, we mainly discussed the use of zebrafish in the research of anti-angiogenic compounds, neuroprotective drugs, and oculotoxicity.

\subsection{Anti-Angiogenic Compounds}

The chemical testing in zebrafish can screen for new anti-angiogenic drugs for the eye diseases, which is analogous to the in vitro/ex vivo platforms. Therefore, zebrafish has been emerging as an exciting new model organism to discover anti-angiogenic drugs for ocular diseases. For instance, the screening of approximately 2000 compounds reveals that four small molecules affect retinal vessel morphology but do not produce obvious changes in the zebrafish trunk vessels and the retinal neuronal architecture [140]. Similarly, a bioactive chemical library of 465 drugs has been screened to identify small molecule inhibitors for the hyaloid vasculature angiogenesis in zebrafish larvae, and the researchers found 10 effective compounds, among which VDR agonists are the most effective ones [19].

In a small chemical screen using zebrafish, LY294002, the PI3K inhibitor, is identified as an effective and selective inhibitor of ocular angiogenesis without systemic side effects and diminishing visual function [141]. Additionally, zebrafish can serve as an early model for testing anti-VEGF drugs by investigating the effect on angiogenesis and its cytotoxicity. The inhibitor of FGFR and VEGFR, brivanib, inhibits zebrafish embryonic angiogenesis without impairing neurodevelopment [142]. Furthermore, both sunitinib and ZM323881, the anti-VEGF agents, can effectively block hypoxia-induced neovascularization in zebrafish [103]. In addition, the VEGFR2 inhibitors, such as sunitinib and 676475 , block the retinal neovascularization in $v$ hl zebrafish $[105,143]$. A recent study also concludes that the orthogonal drug pooling strategy is a cost-effective, time-saving, and unbiased approach to discover novel inhibitors for the ocular angiogenesis in zebrafish larvae [144].

\subsection{Neuroprotective Drugs}

Zebrafish models of the photoreceptor disease provide a platform for discovering novel neuroprotective drugs. Zebrafish can be utilized as phenotypes in screening neuroactive compounds for photoreceptor degeneration [145-147]. An ENZO SCREEN-WELL REDOX library on a zebrafish autosomal dominant RP model finds that carvedilol, a beta-blocker, can increase the rod number and improve visual function [148]. Schisandrin $\mathrm{B}$, an active component isolated from the traditional Chinese medicine (Fructus Schisandrae), is observed to improve light sensation in the pde6c zebrafish model of retinal degeneration [149].

The overactivation of histone deacetylases (HDACs) has been detected in models of photoreceptor degeneration, and HDAC6 inhibition may prevent neurodegeneration [150]. Moreover, it is important to note that HDACs inhibitors can also prevent photoreceptors from light injury-caused death [151]. In the atp6v0e mutant zebrafish model, a cone photoreceptor degeneration disease, HDAC6 inhibitors successfully reduce the number of apoptotic cells and improve the photoreceptor OS area and visual function [152-154]. 
Furthermore, HDAC6 inhibitions and the regulation of peroxiredoxin activity may play a significant role in protecting retinal cells and particular photoreceptors, indicating they are sufficient to rescue retinal cell death and visual function [153].

\subsection{Drug Oculotoxicity}

It is conceivable that many drugs possess oculotoxicity. The prolonged or high-dose exposure to a certain drug may cause eye damage and vision loss. Given that the vertebrate eye is highly conserved, zebrafish can be a useful model for studying the ocular toxicity of drugs [155]. Zebrafish as an efficient animal model can predict the adverse ocular effects at the preclinical stage [156]. In this study, a group of 3-dpf-old zebrafish larvae are treated with drugs for 2 days, and then, the visual behavior is assessed by visual motor response and optokinetic response. Five of the six known oculotoxic drugs, including digoxin, gentamicin, ibuprofen, minoxidil, and quinine, also show some adverse effects on the visual responses of zebrafish. However, zebrafish retina has a different reactivity pattern from mammalian animals against some typical retinal toxicants in terms of histopathology, such as sodium iodate and N-methyl-N-nitrosourea [157]. Overall, when demonstrating the utility for detecting oculotoxic chemicals, the zebrafish assays have a sensitivity and specificity of $68-83 \%$ and $75-100 \%$, respectively [155]. In addition, the chronic exposure to medroxyprogesterone acetate, an action of progesterone, can result in the overgrowth of the eyes and the defective visual functions in zebrafish [158]. These findings suggest that zebrafish models are powerful in resembling oculotoxic characteristics of drugs in humans and predicting oculotoxicity profiles of novel drugs.

\section{Conclusions}

Zebrafish provides a convenient animal model for mechanism investigation and drug discovery in ophthalmology due to their similar eye structure with human and accessibility to genetic manipulation. In the last few years, genome editing technologies, particularly based on Crispr/Cas9, have made it fairly easy to generate lines of zebrafish with mutations in targeted genes [159]. Hence, we are looking forward to the more popular zebrafish model to fully understand the genetic basis of eye diseases in the near future. Zebrafish has been widely used in drug discovery in ophthalmology, such as the screening of new anti-angiogenic compounds or neuroprotective drugs, and testing oculotoxicity. Rapid advances in high-throughput phenotyping point to the promising applications for zebrafish in drug discovery. Zebrafish has become an increasingly attractive model for understanding various human eye diseases and screening new drugs, whose highlights and drawbacks were summarized in Table 4.

Zebrafish models might be more predominant, powerful, and promising tools for investigating the mechanisms of various human eye diseases and discovering the novel drug therapy in the future. 
Table 4. Highlights and drawbacks of zebrafish models for common ocular diseases.

\begin{tabular}{|c|c|c|}
\hline Disease Model & Highlights & Drawbacks \\
\hline $\begin{array}{c}\text { Corneal } \\
\text { dystrophy }\end{array}$ & Able to identify related specific gene mutations & $\begin{array}{l}\text { Not suitable for modeling } \\
\text { other corneal diseases }\end{array}$ \\
\hline Cataract & $\begin{array}{l}\text { Feasible to study disease mechanisms, especially } \\
\text { those involved in crystallins }\end{array}$ & Unavailable to model ARC \\
\hline \multirow{3}{*}{ Glaucoma } & $\begin{array}{c}\text { Available to test specific hypotheses associated } \\
\text { with glaucoma }\end{array}$ & $\begin{array}{l}\text { Unsuccessful at } \\
\text { establishing POCG models }\end{array}$ \\
\hline & Zebrafish bugeye mutant with high IOP & \multirow{2}{*}{$\begin{array}{l}\text { Regenerative capability of } \\
\text { retinal neurons, especially } \\
\text { RGC cells }\end{array}$} \\
\hline & Able to induce model of RGC loss & \\
\hline \multirow{5}{*}{$\begin{array}{l}\text { Vascular } \\
\text { disease }\end{array}$} & $\begin{array}{l}\text { Available to identify related genes } \\
\text { and mechanisms }\end{array}$ & \multirow{2}{*}{$\begin{array}{l}\text { Regenerative capability of } \\
\text { retinal neurons }\end{array}$} \\
\hline & $\begin{array}{l}\text { Transgenic zebrafish lines expressing fluorescent } \\
\text { reporter proteins in the vascular system }\end{array}$ & \\
\hline & $\begin{array}{l}\text { The } p d x 1 \text { mutant zebrafish presenting } \\
\text { hyperglycemia-induced retinal angiogenesis }\end{array}$ & \multirow{3}{*}{$\begin{array}{l}\text { Without ideal model for } \\
\text { neovascular AMD }\end{array}$} \\
\hline & $\begin{array}{l}\text { Transgenic overexpression of human HTRA1 } \\
\text { zebrafish eye with the features of early AMD }\end{array}$ & \\
\hline & $\begin{array}{l}\text { Feasible to help screen new } \\
\text { anti-angiogenic drugs }\end{array}$ & \\
\hline \multirow{3}{*}{$\begin{array}{l}\text { Photoreceptor } \\
\text { Degeneration }\end{array}$} & $\begin{array}{c}\text { Available to have large array of functional and } \\
\text { behavioral tests }\end{array}$ & \multirow{3}{*}{$\begin{array}{l}\text { Regenerative capability of } \\
\text { retinal neurons }\end{array}$} \\
\hline & $\begin{array}{l}\text { Able to identify new neuroprotective drugs } \\
\text { using large-scale discovery }\end{array}$ & \\
\hline & $\begin{array}{l}\text { Feasible to identify related mutations by } \\
\text { genetic screens }\end{array}$ & \\
\hline
\end{tabular}

Author Contributions: Y.H. and Y.L. conceptualized and wrote the paper. Both authors have read and agreed to the published version of the manuscript.

Funding: This work was supported by the National Natural Science Foundation of China to Y.L (81770971); and the Natural Science Foundation of Guangdong Province, China to Y.L (2020A1515010617).

Institutional Review Board Statement: Not applicable.

Informed Consent Statement: Not applicable.

Data Availability Statement: Data sharing not applicable.

Conflicts of Interest: The authors declare no conflict of interest.

\section{References}

1. Bourne, R.; Steinmetz, J.D.; Flaxman, S.; Briant, P.S.; Taylor, H.R.; Resnikoff, S.; Casson, R.J.; Abdoli, A.; Abu-Gharbieh, E.; Afshin, A.; et al. Trends in prevalence of blindness and distance and near vision impairment over 30 years: An analysis for the Global Burden of Disease Study. Lancet Glob. Health 2021, 9, e130-e143. [CrossRef]

2. Steinmetz, J.D.; Bourne, R.R.A.; Briant, P.S.; Flaxman, S.R.; Taylor, H.R.B.; Jonas, J.B.; Abdoli, A.A.; Abrha, W.A.; Abualhasan, A.; Abu-Gharbieh, E.G.; et al. Causes of blindness and vision impairment in 2020 and trends over 30 years, and prevalence of avoidable blindness in relation to VISION 2020: The Right to Sight: An analysis for the Global Burden of Disease Study. Lancet Glob. Health 2021, 9, e144-e160. [CrossRef]

3. Bibliowicz, J.; Tittle, R.K.; Gross, J.M. Toward a better understanding of human eye disease insights from the zebrafish, Danio rerio. Prog. Mol. Biol. Transl. Sci. 2011, 100, 287-330. [CrossRef]

4. Ablain, J.; Zon, L.I. Of fish and men: Using zebrafish to fight human diseases. Trends Cell Biol. 2013, 23, 584-586. [CrossRef]

5. MacRae, C.A.; Peterson, R.T. Zebrafish as tools for drug discovery. Nat. Rev. Drug Discov. 2015, 14, 721-731. [CrossRef] [PubMed]

6. Richardson, R.; Tracey-White, D.; Webster, A.; Moosajee, M. The zebrafish eye-a paradigm for investigating human ocular genetics. Eye 2017, 31, 68-86. [CrossRef] 
7. Zhao, X.C.; Yee, R.W.; Norcom, E.; Burgess, H.; Avanesov, A.S.; Barrish, J.P.; Malicki, J. The Zebrafish Cornea: Structure and Development. Investig. Opthalmol. Vis. Sci. 2006, 47, 4341-4348. [CrossRef] [PubMed]

8. Puzzolo, D.; Pisani, A.; Malta, C.; Santoro, G.; Meduri, A.; Abbate, F.; Montalbano, G.; Wylegala, E.; Rana, R.A.; Bucchieri, F.; et al. Structural, ultrastructural, and morphometric study of the zebrafish ocular surface: A model for human corneal diseases? Curr. Eye Res. 2018, 43, 175-185. [CrossRef] [PubMed]

9. Gestri, G.; Link, B.A.; Neuhauss, S.C. The visual system of zebrafish and its use to model human ocular diseases. Dev. Neurobiol. 2012, 72, 302-327. [CrossRef] [PubMed]

10. Link, B.A.; Gray, M.P.; Smith, R.S.; John, S.W.M. Intraocular Pressure in Zebrafish: Comparison of Inbred Strains and Identification of a Reduced Melanin Mutant with Raised IOP. Investig. Opthalmol. Vis. Sci. 2004, 45, 4415-4422. [CrossRef]

11. Dahm, R.; Schonthaler, H.B.; Soehn, A.S.; van Marle, J.; Vrensen, G.F. Development and adult morphology of the eye lens in the zebrafish. Exp. Eye Res. 2007, 85, 74-89. [CrossRef]

12. Vihtelic, T.S. Teleost Lens Development and Degeneration. Int. Rev. Cell Mol. Biol. 2008, 269, 341-373. [CrossRef] [PubMed]

13. Noel, N.C.L.; Macdonald, I.M.; Allison, W.T. Zebrafish Models of Photoreceptor Dysfunction and Degeneration. Biomolecules 2021, 11, 78. [CrossRef] [PubMed]

14. Yoshimatsu, T.; Schröder, C.; Nevala, N.E.; Berens, P.; Baden, T. Fovea-like Photoreceptor Specializations Underlie Single UV Cone Driven Prey-Capture Behavior in Zebrafish. Neuron 2020, 107, 320-337.e6. [CrossRef]

15. Portugues, R.; Engert, F. The neural basis of visual behaviors in the larval zebrafish. Curr. Opin. Neurobiol. 2009, $19,644-647$. [CrossRef] [PubMed]

16. Bollmann, J.H. The Zebrafish Visual System: From Circuits to Behavior. Annu. Rev. Vis. Sci. 2019, 5, 269-293. [CrossRef]

17. Hartsock, A.; Lee, C.; Arnold, V.; Gross, J.M. In vivo analysis of hyaloid vasculature morphogenesis in zebrafish: A role for the lens in maturation and maintenance of the hyaloid. Dev. Biol. 2014, 394, 327-339. [CrossRef] [PubMed]

18. Rezzola, S.; Belleri, M.; Gariano, G.; Ribatti, D.; Costagliola, C.; Semeraro, F.; Presta, M. In vitro and ex vivo retina angiogenesis assays. Angiogenesis 2013, 17, 429-442. [CrossRef]

19. Merrigan, S.L.; Kennedy, B.N. Vitamin D receptor agonists regulate ocular developmental angiogenesis and modulate expression of dre-miR-21 and VEGF. Br. J. Pharmacol. 2017, 174, 2636-2651. [CrossRef]

20. Alvarez, Y.; Cederlund, M.L.; Cottell, D.C.; Bill, B.R.; Ekker, S.C.; Torres-Vazquez, J.; Weinstein, B.M.; Hyde, D.R.; Vihtelic, T.S.; Kennedy, B.N. Genetic determinants of hyaloid and retinal vasculature in zebrafish. BMC Dev. Biol. 2007, 7, 114. [CrossRef]

21. Xie, J.; Farage, E.; Sugimoto, M.; Anand-Apte, B. A novel transgenic zebrafish model for blood-brain and blood-retinal barrier development. BMC Dev. Biol. 2010, 10, 76. [CrossRef]

22. Lu, J.; Liu, R.; Miao, A.; Chen, X.; Xiao, W.; Wang, Y.; Cao, D.; Pan, J.; Li, L.; Luo, Y. The role of cldnh during the early retinal development in zebrafish. Exp. Eye Res. 2020, 200, 108207. [CrossRef]

23. Lawson, N.; Weinstein, B.M. In Vivo Imaging of Embryonic Vascular Development Using Transgenic Zebrafish. Dev. Biol. 2002, 248, 307-318. [CrossRef]

24. Choi, J.; Dong, L.; Ahn, J.; Dao, D.; Hammerschmidt, M.; Chen, J.-N. FoxH1 negatively modulates flk1 gene expression and vascular formation in zebrafish. Dev. Biol. 2007, 304, 735-744. [CrossRef] [PubMed]

25. Olivares, A.M.; Althoff, K.; Chen, G.F.; Wu, S.; Morrisson, M.A.; DeAngelis, M.M.; Haider, N. Animal Models of Diabetic Retinopathy. Curr. Diabetes Rep. 2017, 17, 93. [CrossRef] [PubMed]

26. Blanco-Sánchez, B.; Clément, A.; Phillips, J.; Westerfield, M. Zebrafish models of human eye and inner ear diseases. Methods Cell Biol. 2017, 138, 415-467. [CrossRef] [PubMed]

27. Easter, J.S.S.; Nicola, G.N. The Development of Vision in the Zebrafish (Danio rerio). Dev. Biol. 1996, 180, 646-663. [CrossRef] [PubMed]

28. Stella, S.; Geathers, J.; Weber, S.; Grillo, M.; Barber, A.; Sundstrom, J.; Grillo, S. Neurodegeneration, Neuroprotection and Regeneration in the Zebrafish Retina. Cells 2021, 10, 633. [CrossRef]

29. Schmitt, E.A.; Dowling, J.E. Early-eye morphogenesis in the zebrafish, Brachydanio rerio. J. Comp. Neurol. 1994, $344,532-542$. [CrossRef] [PubMed]

30. Greiling, T.M.; Clark, J.I. Early lens development in the zebrafish: A three-dimensional time-lapse analysis. Dev. Dyn. 2009, 238, 2254-2265. [CrossRef]

31. Greiling, T.M.S.; Aose, M.; Clark, J.I. Cell Fate and Differentiation of the Developing Ocular Lens. Investig. Opthalmol. Vis. Sci. 2010, 51, 1540-1546. [CrossRef]

32. Mochizuki, T.; Luo, Y.-J.; Tsai, H.-F.; Hagiwara, A.; Masai, I. Cell division and cadherin-mediated adhesion regulate lens epithelial cell movement in zebrafish. Development 2017, 144, 708-719. [CrossRef]

33. Gath, N.; Gross, J.M. Zebrafish mab2112 mutants possess severe defects in optic cup morphogenesis, lens and cornea development. Dev. Dyn. 2019, 248, 514-529. [CrossRef] [PubMed]

34. Lisch, W.; Weiss, J.S. Clinical and genetic update of corneal dystrophies. Exp. Eye Res. 2019, 186, 107715. [CrossRef] [PubMed]

35. Boisset, G.; Polok, B.K.; Schorderet, D. Characterization of pip5k3 fleck corneal dystrophy-linked gene in zebrafish. Gene Expr. Patterns 2008, 8, 404-410. [CrossRef]

36. Yeh, L.-K.; Liu, C.-Y.; Chien, C.-L.; Converse, R.L.; Kao, W.W.-Y.; Chen, M.-S.; Hu, F.-R.; Hsieh, F.-J.; Wang, I.-J. Molecular Analysis and Characterization of Zebrafish Keratocan (zKera) Gene. J. Biol. Chem. 2008, 283, 506-517. [CrossRef] [PubMed] 
37. Oliver, V.F.; Van Bysterveldt, K.A.; Cadzow, M.; Steger, B.; Romano, V.; Markie, D.; Hewitt, A.; Mackey, D.A.; Willoughby, C.; Sherwin, T.; et al. A COL17A1 Splice-Altering Mutation Is Prevalent in Inherited Recurrent Corneal Erosions. Ophthalmology 2016, 123, 709-722. [CrossRef] [PubMed]

38. Semina, E.V.; Bosenko, D.V.; Zinkevich, N.C.; Soules, K.A.; Hyde, D.R.; Vihtelic, T.S.; Willer, G.B.; Gregg, R.; Link, B.A. Mutations in laminin alpha 1 result in complex, lens-independent ocular phenotypes in zebrafish. Dev. Biol. 2006, 299, 63-77. [CrossRef] [PubMed]

39. Shiels, A.; Hejtmancik, J.F. Biology of Inherited Cataracts and Opportunities for Treatment. Annu. Rev. Vis. Sci. 2019, 5, 123-149. [CrossRef]

40. Shiels, A.; Bennett, T.M.; Hejtmancik, J.F. Cat-Map: Putting cataract on the map. Mol. Vis. 2010, 16, $2007-2015$.

41. Mishra, S.; Wu, S.-Y.; Fuller, A.W.; Wang, Z.; Rose, K.L.; Schey, K.L.; Mchaourab, H.S. Loss of $\alpha$ B-crystallin function in zebrafish reveals critical roles in the development of the lens and stress resistance of the heart. J. Biol. Chem. 2018, 293, 740-753. [CrossRef] [PubMed]

42. Goishi, K.; Shimizu, A.; Najarro, G.; Watanabe, S.; Rogers, R.; Zon, L.I.; Klagsbrun, M. AlphaA-crystallin expression prevents gamma-crystallin insolubility and cataract formation in the zebrafish cloche mutant lens. Development 2006, 133, 2585-2593. [CrossRef] [PubMed]

43. Aryal, S.; Viet, J.; Weatherbee, B.; Siddam, A.D.; Hernandez, F.G.; Gautier-Courteille, C.; Paillard, L.; Lachke, S.A. The cataractlinked RNA-binding protein Celf1 post-transcriptionally controls the spatiotemporal expression of the key homeodomain transcription factors Pax6 and Prox1 in lens development. Hum. Genet. 2020, 139, 1541-1554. [CrossRef] [PubMed]

44. Heisenberg, C.; Brand, M.; Jiang, Y.; Warga, R.; Beuchle, D.; van Eeden, F.; Furutani-Seiki, M.; Granato, M.; Haffter, P.; Hammerschmidt, M.; et al. Genes involved in forebrain development in the zebrafish, Danio rerio. Development 1996, 123, 191-203. [CrossRef]

45. Shi, X.; Bosenko, D.; Zinkevich, N.; Foley, S.; Hyde, D.; Semina, E.; Vihtelic, T.S. Zebrafish pitx3 is necessary for normal lens and retinal development. Mech. Dev. 2005, 122, 513-527. [CrossRef]

46. Shi, X.; Luo, Y.; Howley, S.; Dzialo, A.; Foley, S.; Hyde, D.R.; Vihtelic, T.S. Zebrafish foxe3: Roles in ocular lens morphogenesis through interaction with pitxMech. Development 2006, 123, 761-782. [CrossRef]

47. Swindell, E.C.; Zilinski, C.A.; Hashimoto, R.; Shah, R.; Lane, M.E.; Jamrich, M. Regulation and function offoxe3 during early zebrafish development. Genes 2008, 46, 177-183. [CrossRef]

48. Anand, D.; Agrawal, S.A.; Slavotinek, A.; Lachke, S.A. Mutation update of transcription factor genes FOXE3, HSF4, MAF, and PITX3 causing cataracts and other developmental ocular defects. Hum. Mutat. 2018, 39, 471-494. [CrossRef]

49. Krall, M.; Htun, S.; Anand, D.; Hart, D.; Lachke, S.A.; Slavotinek, A.M. A zebrafish model of foxe3 deficiency demonstrates lens and eye defects with dysregulation of key genes involved in cataract formation in humans. Hum. Genet. 2018, 137, 315-328. [CrossRef]

50. Gao, M.; Huang, Y.; Wang, L.; Huang, M.; Liu, F.; Liao, S.; Yu, S.; Lu, Z.; Han, S.; Hu, X.; et al. HSF4 regulates lens fiber cell differentiation by activating p53 and its downstream regulators. Cell Death Dis. 2017, 8, e3082. [CrossRef]

51. Shiels, A.; Hejtmancik, J.F. Mutations and mechanisms in congenital and age-related cataracts. Exp. Eye Res. 2017, 156, 95-102. [CrossRef]

52. Greiling, T.M.; Houck, S.A.; Clark, J.I. The zebrafish lens proteome during development and aging. Mol. Vis. 2009, 15, $2313-2325$.

53. Peschek, J.; Braun, N.; Rohrberg, J.; Back, K.C.; Kriehuber, T.; Kastenmüller, A.; Weinkauf, S.; Buchner, J. Regulated structural transitions unleash the chaperone activity of B-crystallin. Proc. Natl. Acad. Sci. USA 2013, 110, E3780-E3789. [CrossRef]

54. Wu, S.-Y.; Zou, P.; Mishra, S.; Mchaourab, H.S. Transgenic zebrafish models reveal distinct molecular mechanisms for cataractlinked $\alpha$ A-crystallin mutants. PLoS ONE 2018, 13, e0207540. [CrossRef]

55. Li, X.-Q.; Cai, H.-C.; Zhou, S.; Yang, J.-H.; Xi, Y.-B.; Gao, X.-B.; Zhao, W.-J.; Li, P.; Zhao, G.-Y.; Tong, Y.; et al. A novel mutation impairing the tertiary structure and stability of $\gamma$ C-crystallin (CRYGC) leads to cataract formation in humans and zebrafish lens. Hum. Mutat. 2012, 33, 391-401. [CrossRef] [PubMed]

56. Wu, S.-Y.; Zou, P.; Fuller, A.W.; Mishra, S.; Wang, Z.; Schey, K.L.; Mchaourab, H.S. Expression of Cataract-linked $\gamma$-Crystallin Variants in Zebrafish Reveals a Proteostasis Network That Senses Protein Stability. J. Biol. Chem. 2016, 291, 25387-25397. [CrossRef]

57. Zhang, J.; Cui, W.-W.; Du, C.; Huang, Y.; Pi, X.; Guo, W.; Wang, J.; Huang, W.; Chen, D.; Li, J.; et al. Knockout of DNase1111 abrogates lens denucleation process and causes cataract in zebrafish. Biochim. Biophys. Acta Mol. Basis Dis. 2020, 1866, 165724. [CrossRef] [PubMed]

58. Harding, P.; Toms, M.; Schiff, E.; Owen, N.; Bell, S.; Lloyd, I.; Moosajee, M. EPHA2 Segregates with Microphthalmia and Congenital Cataracts in Two Unrelated Families. Int. J. Mol. Sci. 2021, 22, 2190. [CrossRef]

59. Taler, K.; Weiss, O.; Rotem-Bamberger, S.; Rubinstein, A.M.; Seritrakul, P.; Gross, J.M.; Inbal, A. Lysyl hydroxylase 3 is required for normal lens capsule formation and maintenance of lens epithelium integrity and fate. Dev. Biol. 2020, 458, 177-188. [CrossRef]

60. Shao, M.; Lu, T.; Zhang, C.; Zhang, Y.-Z.; Kong, S.-H.; Shi, D.-L. Rbm24 controls poly(A) tail length and translation efficiency of crystallin mRNAs in the lens via cytoplasmic polyadenylation. Proc. Natl. Acad. Sci. USA 2020, 117, 7245-7254. [CrossRef] [PubMed]

61. Vorontsova, I.; Gehring, I.; Hall, J.E.; Schilling, T.F. Aqp0a Regulates Suture Stability in the Zebrafish Lens. Investig. Opthalmol. Vis. Sci. 2018, 59, 2869-2879. [CrossRef] 
62. Ping, X.; Liang, J.; Shi, K.; Bao, J.; Wu, J.; Yu, X.; Tang, X.; Zou, J.; Shentu, X. Rapamycin relieves the cataract caused by ablation of Gja8b through stimulating autophagy in zebrafish. Autophagy 2021, 2021, 1-15. [CrossRef]

63. Ping, X.; Cheng, Y.; Bao, J.; Shi, K.; Zou, J.; Shentu, X. KPNA4 is involved in cataract formation via the nuclear import of p53. Gene 2021, 786, 145621. [CrossRef]

64. Jones, J.L.; Corbett, M.A.; Yeaman, E.; Zhao, D.; Gecz, J.; Gasperini, R.J.; Charlesworth, J.C.; Mackey, D.A.; Elder, J.E.; Craig, J.E.; et al. A $127 \mathrm{~kb}$ truncating deletion of PGRMC1 is a novel cause of X-linked isolated paediatric cataract. Eur. J. Hum. Genet. 2021, 1-10. [CrossRef]

65. Siddam, A.D.; Gautier-Courteille, C.; Perez-Campos, L.; Anand, D.; Kakrana, A.; Dang, C.A.; Legagneux, V.; Méreau, A.; Viet, J.; Gross, J.M.; et al. The RNA-binding protein Celf1 post-transcriptionally regulates p27Kip1 and Dnase2b to control fiber cell nuclear degradation in lens development. PLoS Genet. 2018, 14, e1007278. [CrossRef] [PubMed]

66. Liu, Y.; Allingham, R.R. Major review: Molecular genetics of primary open-angle glaucoma. Exp. Eye Res. 2017, 160, 62-84. [CrossRef]

67. Youngblood, H.; Hauser, M.A.; Liu, Y. Update on the genetics of primary open-angle glaucoma. Exp. Eye Res. $2019,188,107795$. [CrossRef]

68. Chen, C.-C.; Yeh, L.-K.; Liu, C.-Y.; Kao, W.W.-Y.; Samples, J.R.; Lin, S.-J.; Hu, F.-R.; Wang, I.-J. Morphological differences between the trabecular meshworks of zebrafish and mammals. Curr. Eye Res. 2008, 33, 59-72. [CrossRef] [PubMed]

69. Gray, M.P.; Smith, R.S.; Soules, K.A.; John, S.W.M.; Link, B.A. The Aqueous Humor Outflow Pathway of Zebrafish. Investig. Opthalmol. Vis. Sci. 2009, 50, 1515-1521. [CrossRef]

70. Iglesias, A.I.; Springelkamp, H.; Van Der Linde, H.; Severijnen, L.-A.; Amin, N.; Oostra, B.; Kockx, C.E.M.; Hout, M.C.G.N.V.D.; Van Ijcken, W.F.J.; Hofman, A.; et al. Exome sequencing and functional analyses suggest that SIX6 is a gene involved in an altered proliferation-differentiation balance early in life and optic nerve degeneration at old age. Hum. Mol. Genet. 2013, 23, 1320-1332. [CrossRef]

71. Carnes, M.; Liu, Y.P.; Allingham, R.R.; Whigham, B.T.; Havens, S.; Garrett, M.E.; Qiao, C.; Katsanis, N.; Wiggs, J.L.; Pasquale, L.R.; et al. Discovery and Functional Annotation of SIX6 Variants in Primary Open-Angle Glaucoma. PLoS Genet. 2014,10 , e1004372. [CrossRef]

72. Shah, M.H.; Tabanera, N.; Krishnadas, S.R.; Pillai, M.R.; Bovolenta, P.; Sundaresan, P. Identification and characterization of variants and a novel $4 \mathrm{bp}$ deletion in the regulatory region of SIX6, a risk factor for primary open-angle glaucoma. Mol. Genet. Genom. Med. 2017, 5, 323-335. [CrossRef] [PubMed]

73. Bailey, J.N.C.; ANZRAG Consortium; Loomis, S.J.; Kang, J.H.; Allingham, R.R.; Gharahkhani, P.; Khor, C.C.; Burdon, K.P.; Aschard, H.; Chasman, D.I.; et al. Genome-wide association analysis identifies TXNRD2, ATXN2 and FOXC1 as susceptibility loci for primary open-angle glaucoma. Nat. Genet. 2016, 48, 189-194. [CrossRef] [PubMed]

74. Berry, F.B.; Skarie, J.M.; Mirzayans, F.; Fortin, Y.; Hudson, T.J.; Raymond, V.; Link, B.A.; Walter, M.A. FOXC1 is required for cell viability and resistance to oxidative stress in the eye through the transcriptional regulation of FOXO1A. Hum. Mol. Genet. 2007, 17, 490-505. [CrossRef] [PubMed]

75. Umali, J.; Hawkey-Noble, A.; French, C.R. Loss of foxc1 in zebrafish reduces optic nerve size and cell number in the retinal ganglion cell layer. Vis. Res. 2019, 156, 66-72. [CrossRef] [PubMed]

76. Veth, K.N.; Willer, J.R.; Collery, R.F.; Gray, M.P.; Willer, G.B.; Wagner, D.S.; Mullins, M.C.; Udvadia, A.J.; Smith, R.S.; John, S.W.M.; et al. Mutations in Zebrafish lrp2 Result in Adult-Onset Ocular Pathogenesis That Models Myopia and Other Risk Factors for Glaucoma. PLoS Genet. 2011, 7, e1001310. [CrossRef] [PubMed]

77. Stujenske, J.M.; Dowling, J.E.; Emran, F. TheBugeyeMutant Zebrafish Exhibits Visual Deficits that Arise with the Onset of an Enlarged Eye Phenotype. Investig. Opthalmol. Vis. Sci. 2011, 52, 4200-4207. [CrossRef] [PubMed]

78. Sheng, W.; Lu, Y.; Mei, F.; Wang, N.; Liu, Z.-Z.; Han, Y.-Y.; Wang, H.-T.; Zou, S.; Xu, H.; Zhang, X. Effect of Resveratrol on Sirtuins, OPA1, and Fis1 Expression in Adult Zebrafish Retina. Investig. Opthalmol. Vis. Sci. 2018, 59, 4542-4551. [CrossRef]

79. Huang, W.; Hu, F.; Wang, M.; Gao, F.; Xu, P.; Xing, C.; Sun, X.; Zhang, S.; Wu, J. Comparative analysis of retinal ganglion cell damage in three glaucomatous rat models. Exp. Eye Res. 2018, 172, 112-122. [CrossRef]

80. Aslan, M.; Cort, A.; Yucel, I. Oxidative and nitrative stress markers in glaucoma. Free. Radic. Biol. Med. 2008, 45, 367-376. [CrossRef]

81. Giannaccini, M.; Usai, A.; Chiellini, F.; Guadagni, V.; Andreazzoli, M.; Ori, M.; Pasqualetti, M.; Dente, L.; Raffa, V. Neurotrophinconjugated nanoparticles prevent retina damage induced by oxidative stress. Cell. Mol. Life Sci. 2018, 75, 1255-1267. [CrossRef]

82. Sherpa, T.; Fimbel, S.M.; Mallory, D.E.; Maaswinkel, H.; Spritzer, S.D.; Sand, J.A.; Li, L.; Hyde, D.R.; Stenkamp, D.L. Ganglion cell regeneration following whole-retina destruction in zebrafish. Dev. Neurobiol. 2007, 68, 166-181. [CrossRef] [PubMed]

83. Bonet-Fernández, J.-M.; Aroca-Aguilar, J.-D.; Corton, M.; Ramírez, A.-I.; Alexandre-Moreno, S.; García-Antón, M.-T.; Salazar, J.-J.; Ferre-Fernández, J.-J.; Atienzar-Aroca, R.; Villaverde, C.; et al. CPAMD8 loss-of-function underlies non-dominant congenital glaucoma with variable anterior segment dysgenesis and abnormal extracellular matrix. Hum Genet. 2020, 139, $1209-1231$. [CrossRef] [PubMed]

84. Williams, A.L.; Eason, J.; Chawla, B.; Bohnsack, B.L. Cyp1b1 Regulates Ocular Fissure Closure through a Retinoic AcidIndependent Pathway. Investig. Opthalmol. Vis. Sci. 2017, 58, 1084-1097. [CrossRef]

85. Skarie, J.M.; Link, B.A. FoxC1Is Essential for Vascular Basement Membrane Integrity and Hyaloid Vessel Morphogenesis. Investig. Opthalmol. Vis. Sci. 2009, 50, 5026-5034. [CrossRef] 
86. Ferre-Fernández, J.-J.; Aroca-Aguilar, J.-D.; Medina-Trillo, C.; Bonet-Fernández, J.-M.; Méndez-Hernández, C.-D.; MoralesFernández, L.; Corton, M.; Cabañero-Valera, M.-J.; Gut, M.; Tonda, R.; et al. Whole-Exome Sequencing of Congenital Glaucoma Patients Reveals Hypermorphic Variants in GPATCH3, a New Gene Involved in Ocular and Craniofacial Development. Sci. Rep. 2017, 7, 46175. [CrossRef] [PubMed]

87. Morales-Cámara, S.; Alexandre-Moreno, S.; Bonet-Fernández, J.-M.; Atienzar-Aroca, R.; Aroca-Aguilar, J.-D.; Ferre-Fernández, J.-J.; Méndez, C.-D.; Morales, L.; Fernández-Sánchez, L.; Cuenca, N.; et al. Role of GUCA1C in Primary Congenital Glaucoma and in the Retina: Functional Evaluation in Zebrafish. Genes 2020, 11, 550. [CrossRef] [PubMed]

88. Luo, N.; West, C.C.; Murga-Zamalloa, C.A.; Sun, L.; Anderson, R.M.; Wells, C.D.; Weinreb, R.N.; Travers, J.; Khanna, H.; Sun, Y. OCRL localizes to the primary cilium: A new role for cilia in Lowe syndrome. Hum. Mol. Genet. 2012, 21, 3333-3344. [CrossRef]

89. Hendee, K.E.; Sorokina, E.A.; Muheisen, S.S.; Reis, L.M.; Tyler, R.C.; Markovic, V.; Cuturilo, G.; Link, B.A.; Semina, E.V. PITX2 deficiency and associated human disease: Insights from the zebrafish model. Hum. Mol. Genet. 2018, 27, 1675-1695. [CrossRef] [PubMed]

90. Lahola-Chomiak, A.A.; Footz, T.; Nguyen-Phuoc, K.; Neil, G.J.; Fan, B.; Allen, K.F.; Greenfield, D.S.; Parrish, R.K.; Linkroum, K.; Pasquale, L.R.; et al. Non-Synonymous variants in premelanosome protein (PMEL) cause ocular pigment dispersion and pigmentary glaucoma. Hum. Mol. Genet. 2018, 28, 1298-1311. [CrossRef]

91. Protas, M.E.; Weh, E.; Footz, T.; Kasberger, J.; Baraban, S.C.; Levin, A.V.; Katz, L.J.; Ritch, R.; Walter, M.A.; Semina, E.V.; et al. Mutations of conserved non-coding elements of PITX2 in patients with ocular dysgenesis and developmental glaucoma. Hum. Mol. Genet. 2017, 26, 3630-3638. [CrossRef]

92. Gallenberger, M.; Meinel, D.; Kroeber, M.; Wegner, M.; Milkereit, P.; Bösl, M.R.; Tamm, E.R. Lack of WDR36 leads to preimplantation embryonic lethality in mice and delays the formation of small subunit ribosomal RNA in human cells in vitro. Hum. Mol. Genet. 2010, 20, 422-435. [CrossRef]

93. Heckler, K.; Kroll, J. Zebrafish as a Model for the Study of Microvascular Complications of Diabetes and Their Mechanisms. Int. J. Mol. Sci. 2017, 18, 2002. [CrossRef] [PubMed]

94. Gleeson, M.; Connaughton, V.; Arneson, L.S. Induction of hyperglycaemia in zebrafish (Danio rerio) leads to morphological changes in the retina. Acta Diabetol. 2007, 44, 157-163. [CrossRef]

95. Alvarez, Y.; Chen, K.; Reynolds, A.; Waghorne, N.; O'Connor, J.; Kennedy, B. Predominant cone photoreceptor dysfunction in a hyperglycaemic model of non-proliferative diabetic retinopathy. Dis. Model. Mech. 2010, 3, 236-245. [CrossRef]

96. Tanvir, Z.; Nelson, R.F.; DeCicco-Skinner, K.; Connaughton, V.P. One month of hyperglycemia alters spectral responses of the zebrafish photopic electroretinogram. Dis. Model. Mech. 2018, 11. [CrossRef] [PubMed]

97. Jung, S.-H.; Kim, Y.S.; Lee, Y.-R.; Kim, J.S. High glucose-induced changes in hyaloid-retinal vessels during early ocular development of zebrafish: A short-term animal model of diabetic retinopathy. Br. J. Pharmacol. 2015, 173, 15-26. [CrossRef] [PubMed]

98. Ali, Z.; Zang, J.; Lagali, N.; Schmitner, N.; Salvenmoser, W.; Mukwaya, A.; Neuhauss, S.C.; Jensen, L.D.; Kimmel, R.A. Photoreceptor Degeneration Accompanies Vascular Changes in a Zebrafish Model of Diabetic Retinopathy. Investig. Opthalmol. Vis. Sci. 2020, 61, 43. [CrossRef]

99. Salehpour, A.; Rezaei, M.; Khoradmehr, A.; Tahamtani, Y.; Tamadon, A. Which Hyperglycemic Model of Zebrafish (Danio rerio) Suites My Type 2 Diabetes Mellitus Research? A Scoring System for Available Methods. Front. Cell Dev. Biol. 2021, 9. [CrossRef] [PubMed]

100. Lee, Y.; Yang, J. Development of a zebrafish screening model for diabetic retinopathy induced by hyperglycemia: Reproducibility verification in animal model. Biomed. Pharmacother. 2021, 135, 111201. [CrossRef] [PubMed]

101. Sen, P.; Wu, W.-C.; Chandra, P.; Vinekar, A.; Manchegowda, P.T.; Bhende, P. Retinopathy of prematurity treatment: Asian perspectives. Eye 2020, 34, 632-642. [CrossRef]

102. Wu, Y.-C.; Chang, C.-Y.; Kao, A.; Hsi, B.; Lee, S.-H.; Chen, Y.-H.; Wang, I.-J. Hypoxia-Induced Retinal Neovascularization in Zebrafish Embryos: A Potential Model of Retinopathy of Prematurity. PLoS ONE 2015, 10, e0126750. [CrossRef]

103. Cao, Z.; Jensen, L.D.; Rouhi, P.; Hosaka, K.; Länne, T.; Steffensen, J.F.; Wahlberg, E.; Cao, Y. Hypoxia-induced retinopathy model in adult zebrafish. Nat. Protoc. 2010, 5, 1903-1910. [CrossRef] [PubMed]

104. Mitchell, P.; Liew, G.; Gopinath, B.; Wong, T.Y. Age-related macular degeneration. Lancet 2018, 392, 1147-1159. [CrossRef]

105. van Rooijen, E.; Voest, E.E.; Logister, I.; Bussmann, J.; Korving, J.; van Eeden, F.J.; Giles, R.H.; Schulte-Merker, S. von HippelLindau tumor suppressor mutants faithfully model pathological hypoxia-driven angiogenesis and vascular retinopathies in zebrafish. Dis. Model. Mech. 2010, 3, 343-353. [CrossRef]

106. Biehlmaier, O.; Neuhauss, S.C.F.; Kohler, K. Double cone dystrophy and RPE degeneration in the retina of the zebrafish gnn mutant. Investig. Opthalmol. Vis. Sci. 2003, 44, 1287-1298. [CrossRef] [PubMed]

107. Oura, Y.; Nakamura, M.; Takigawa, T.; Fukushima, Y.; Wakabayashi, T.; Tsujikawa, M.; Nishida, K. High-Temperature Requirement A 1 Causes Photoreceptor Cell Death in Zebrafish Disease Models. Am. J. Pathol. 2018, 188, 2729-2744. [CrossRef] [PubMed]

108. Noel, N.C.L.; Nadolski, N.J.; Hocking, J.C.; Macdonald, I.M.; Allison, W.T. Progressive Photoreceptor Dysfunction and AgeRelated Macular Degeneration-Like Features in rp111 Mutant Zebrafish. Cells 2020, 9, 2214. [CrossRef]

109. Bujakowska, K.; Liu, Q.; Pierce, E.A. Photoreceptor Cilia and Retinal Ciliopathies. Cold Spring Harb. Perspect. Biol. 2017, 9, a028274. [CrossRef] 
110. Nakao, T.; Tsujikawa, M.; Notomi, S.; Ikeda, Y.; Nishida, K. The Role of Mislocalized Phototransduction in Photoreceptor Cell Death of Retinitis Pigmentosa. PLoS ONE 2012, 7, e32472. [CrossRef]

111. Zelinka, C.P.; Sotolongo-Lopez, M.; Fadool, J.M. Targeted disruption of the endogenous zebrafish rhodopsin locus as models of rapid rod photoreceptor degeneration. Mol. Vis. 2018, 24, 587-602. [PubMed]

112. Eroglu, A.U.; Mulligan, T.S.; Zhang, L.; White, D.T.; Sengupta, S.; Nie, C.; Lu, N.Y.; Qian, J.; Xu, L.; Pei, W.; et al. Multiplexed CRISPR/Cas9 Targeting of Genes Implicated in Retinal Regeneration and Degeneration. Front. Cell Dev. Biol. 2018, 6, 88. [CrossRef] [PubMed]

113. Lyraki, R.; Megaw, R.; Hurd, T. Disease mechanisms of X-linked retinitis pigmentosa due to RP2 and RPGR mutations. Biochem. Soc. Trans. 2016, 44, 1235-1244. [CrossRef] [PubMed]

114. Shu, X.; Zeng, Z.; Gautier, P.; Lennon, A.; Gakovic, M.; Cheetham, M.; Patton, E.E.; Wright, A.F. Knockdown of the Zebrafish Ortholog of the Retinitis Pigmentosa 2 (RP2) Gene Results in Retinal Degeneration. Investig. Opthalmol. Vis. Sci. 2011, 52, 2960-2966. [CrossRef]

115. Liu, F.; Chen, J.; Yu, S.; Raghupathy, R.K.; Liu, X.; Qin, Y.; Li, C.; Huang, M.; Liao, S.; Wang, J.; et al. Knockout ofRP2decreases GRK1 and rod transducin subunits and leads to photoreceptor degeneration in zebrafish. Hum. Mol. Genet. 2015, 24, 4648-4659. [CrossRef]

116. Shu, X.; Zeng, Z.; Gautier, P.; Lennon, A.; Gakovic, M.; Patton, E.E.; Wright, A.F. Zebrafish Rpgr is required for normal retinal development and plays a role in dynein-based retrograde transport processes. Hum. Mol. Genet. 2009, 19, 657-670. [CrossRef]

117. Zhang, J.; Wang, C.; Shen, Y.; Chen, N.; Wang, L.; Liang, L.; Guo, T.; Yin, X.; Ma, Z.; Zhang, B.; et al. A mutation in ADIPOR1 causes nonsyndromic autosomal dominant retinitis pigmentosa. Hum. Genet. 2016, 135, 1375-1387. [CrossRef]

118. Yu, S.; Li, C.; Biswas, L.; Hu, X.; Liu, F.; Reilly, J.; Liu, X.; Liu, Y.; Huang, Y.; Lu, Z.; et al. CERKL gene knockout disturbs photoreceptor outer segment phagocytosis and causes rod-cone dystrophy in zebrafish. Hum. Mol. Genet. 2017, 26, 2335-2345. [CrossRef]

119. Yi, Z.; Ouyang, J.; Sun, W.; Li, S.; Xiao, X.; Zhang, Q. Comparative exome sequencing reveals novel candidate genes for retinitis pigmentosa. EBioMedicine 2020, 56, 102792. [CrossRef] [PubMed]

120. Lu, Z.; Hu, X.; Liu, F.; Soares, D.; Liu, X.; Yu, S.; Gao, M.; Han, S.; Qin, Y.; Li, C.; et al. Ablation of EYS in zebrafish causes mislocalisation of outer segment proteins, F-actin disruption and cone-rod dystrophy. Sci. Rep. 2017, 7, srep46098. [CrossRef]

121. Coomer, C.E.; Wilson, S.G.; Titialii-Torres, K.F.; Bills, J.D.; Krueger, L.A.; Petersen, R.A.; Turnbaugh, E.M.; Janesch, E.L.; Morris, A.C. Her9/Hes4 is required for retinal photoreceptor development, maintenance, and survival. Sci. Rep. 2020, 10, 1-20. [CrossRef] [PubMed]

122. Feng, D.; Chen, Z.; Yang, K.; Miao, S.; Xu, B.; Kang, Y.; Xie, H.; Zhao, C. The cytoplasmic tail of rhodopsin triggers rapid rod degeneration in kinesin-2 mutants. J. Biol. Chem. 2017, 292, 17375-17386. [CrossRef] [PubMed]

123. Wasfy, M.M.; Matsui, J.I.; Miller, J.; Dowling, J.E.; Perkins, B.D. myosin 7aa-/-mutant zebrafish show mild photoreceptor degeneration and reduced electroretinographic responses. Exp. Eye Res. 2014, 122, 65-76. [CrossRef] [PubMed]

124. Hubshman, M.W.; Broekman, S.; Van Wijk, E.; Cremers, F.; Abu-Diab, A.; Khateb, S.; Tzur, S.; Lagovsky, I.; Smirin-Yosef, P.; Sharon, D.; et al. Whole-exome sequencing reveals POC5 as a novel gene associated with autosomal recessive retinitis pigmentosa. Hum. Mol. Genet. 2017, 27, 614-624. [CrossRef]

125. Lu, Z.; Hu, X.; Reilly, J.; Jia, D.; Liu, F.; Yu, S.; Liu, X.; Xie, S.; Qu, Z.; Qin, Y.; et al. Deletion of the transmembrane protein Prom1b in zebrafish disrupts outer-segment morphogenesis and causes photoreceptor degeneration. J. Biol. Chem. 2019, 294, 13953-13963. [CrossRef]

126. Li, J.; Liu, F.; Lv, Y.; Sun, K.; Zhao, Y.; Reilly, J.; Zhang, Y.; Tu, J.; Yu, S.; Liu, X.; et al. Prpf31 is essential for the survival and differentiation of retinal progenitor cells by modulating alternative splicing. Nucleic Acids Res. 2021, 49, 2027-2043. [CrossRef]

127. Zhuang, Y.-Y.; Xiang, L.; Wen, X.-R.; Shen, R.-J.; Zhao, N.; Zheng, S.-S.; Han, R.-Y.; Qu, J.; Lu, F.; Jin, Z.-B. Slc7a14 Is Indispensable in Zebrafish Retinas. Front. Cell Dev. Biol. 2019, 7, 333. [CrossRef]

128. Zhang, T.; Bai, J.; Zhang, X.; Zheng, X.; Lu, N.; Liang, Z.; Lin, L.; Chen, Y. SNRNP200 Mutations Cause Autosomal Dominant Retinitis Pigmentosa. Front. Med. 2021, 7. [CrossRef]

129. Han, S.; Liu, X.; Xie, S.; Gao, M.; Liu, F.; Yu, S.; Sun, P.; Wang, C.; Archacki, S.; Lu, Z.; et al. Knockout of ush2a gene in zebrafish causes hearing impairment and late onset rod-cone dystrophy. Hum. Genet. 2018, 137, 779-794. [CrossRef] [PubMed]

130. Kondkar, A.A.; Abu-Amero, K.K. Leber congenital amaurosis: Current genetic basis, scope for genetic testing and personalized medicine. Exp. Eye Res. 2019, 189, 107834. [CrossRef]

131. Baye, L.M.; Patrinostro, X.; Swaminathan, S.; Beck, J.S.; Zhang, Y.; Stone, E.M.; Sheffield, V.C.; Slusarski, D.C. The N-terminal region of centrosomal protein 290 (CEP290) restores vision in a zebrafish model of human blindness. Hum. Mol. Genet. 2011, 20, 1467-1477. [CrossRef] [PubMed]

132. Qu, Z.; Yimer, T.A.; Xie, S.; Wong, F.; Yu, S.; Liu, X.; Han, S.; Ma, J.; Lu, Z.; Hu, X.; et al. Knocking out lca5 in zebrafish causes cone-rod dystrophy due to impaired outer segment protein trafficking. Biochim. Biophys. Acta Mol. Basis Dis. 2019, 1865, $2694-2705$. [CrossRef] [PubMed]

133. Kumaran, N.; Moore, A.T.; Weleber, R.G.; Michaelides, M. Leber congenital amaurosis/early-onset severe retinal dystrophy: Clinical features, molecular genetics and therapeutic interventions. Br. J. Ophthalmol. 2017, 101, 1147-1154. [CrossRef] [PubMed]

134. Krock, B.L.; Perkins, B.D. The intraflagellar transport protein IFT57 is required for cilia maintenance and regulates IFT-particlekinesin-II dissociation in vertebrate photoreceptors. J. Cell Sci. 2008, 121, 1907-1915. [CrossRef] [PubMed] 
135. Sukumaran, S.; Perkins, B.D. Early defects in photoreceptor outer segment morphogenesis in zebrafish ift57, ift 88 and ift 172 Intraflagellar Transport mutants. Vis. Res. 2009, 49, 479-489. [CrossRef]

136. Lee, C.; Wallingford, J.B.; Gross, J.M. Cluap1 is essential for ciliogenesis and photoreceptor maintenance in the vertebrate eye. Invest. Ophthalmol. Vis. Sci. 2014, 55, 4585-4592. [CrossRef]

137. Pooranachandran, N.; Malicki, J.J. Unexpected Roles for Ciliary Kinesins and Intraflagellar Transport Proteins. Genetics 2016, 203, 771-785. [CrossRef] [PubMed]

138. Raghupathy, R.K.; Zhang, X.; Alhasani, R.H.; Zhou, X.; Mullin, M.; Reilly, J.; Li, W.-C.; Liu, M.; Shu, X. Abnormal photoreceptor outer segment development and early retinal degeneration inkif3amutant zebrafish. Cell Biochem. Funct. 2016, 34, 429-440. [CrossRef]

139. Das, B.C.; McCormick, L.; Thapa, P.; Karki, R.; Evans, T. Use of zebrafish in chemical biology and drug discovery. Future Med. Chem. 2013, 5, 2103-2116. [CrossRef]

140. Kitambi, S.S.; McCulloch, K.J.; Peterson, R.T.; Malicki, J.J. Small molecule screen for compounds that affect vascular development in the zebrafish retina. Mech. Dev. 2009, 126, 464-477. [CrossRef] [PubMed]

141. Alvarez, Y.; Astudillo, O.; Jensen, L.; Reynolds, A.L.; Waghorne, N.; Brazil, D.; Cao, Y.; O’Connor, J.J.; Kennedy, B.N. Selective Inhibition of Retinal Angiogenesis by Targeting PI3 Kinase. PLoS ONE 2009, 4, e7867. [CrossRef] [PubMed]

142. Li, L.; Zhu, M.; Wu, W.; Qin, B.; Gu, J.; Tu, Y.; Chen, J.; Liu, D.; Shi, Y.; Liu, X.; et al. Brivanib, a multitargeted small-molecule tyrosine kinase inhibitor, suppresses laser-induced CNV in a mouse model of neovascular AMD. J. Cell. Physiol. 2020, 235, 1259-1273. [CrossRef]

143. Arjamaa, O.; Nikinmaa, M. Oxygen-dependent diseases in the retina: Role of hypoxia-inducible factors. Exp. Eye Res. 2006, 83, 473-483. [CrossRef]

144. Ohnesorge, N.; Sasore, T.; Hillary, D.; Alvarez, Y.; Carey, M.; Kennedy, B.N. Orthogonal Drug Pooling Enhances Phenotype-Based Discovery of Ocular Antiangiogenic Drugs in Zebrafish Larvae. Front. Pharmacol. 2019, 10, 508. [CrossRef]

145. Rihel, J.; Prober, D.A.; Arvanites, A.; Lam, K.; Zimmerman, S.; Jang, S.; Haggarty, S.J.; Kokel, D.; Rubin, L.; Peterson, R.T.; et al. Zebrafish Behavioral Profiling Links Drugs to Biological Targets and Rest/Wake Regulation. Science 2010, 327, 348-351. [CrossRef] [PubMed]

146. Kokel, D.; Bryan, J.; Laggner, C.; White, R.; Cheung, C.Y.J.; Mateus, R.; Healey, D.; Kim, S.; Werdich, A.A.; Haggarty, S.J.; et al. Rapid behavior-based identification of neuroactive small molecules in the zebrafish. Nat. Chem. Biol. 2010, 6, 231-237. [CrossRef] [PubMed]

147. Ganzen, L.; Venkatraman, P.; Pang, C.P.; Leung, Y.F.; Zhang, M. Utilizing Zebrafish Visual Behaviors in Drug Screening for Retinal Degeneration. Int. J. Mol. Sci. 2017, 18, 1185. [CrossRef] [PubMed]

148. Ganzen, L.; Ko, M.J.; Zhang, M.; Xie, R.; Chen, Y.; Zhang, L.; James, R.; Mumm, J.; van Rijn, R.M.; Zhong, W.; et al. Drug screening with zebrafish visual behavior identifies carvedilol as a potential treatment for an autosomal dominant form of retinitis pigmentosa. Sci. Rep. 2021, 11, 1-14. [CrossRef]

149. Zhang, L.; Xiang, L.; Liu, Y.; Venkatraman, P.; Chong, L.; Cho, J.; Bonilla, S.; Jin, Z.-B.; Pang, C.P.; Ko, K.M.; et al. A NaturallyDerived Compound Schisandrin B Enhanced Light Sensation in the pde6c Zebrafish Model of Retinal Degeneration. PLoS ONE 2016, 11, e0149663. [CrossRef]

150. Sancho-Pelluz, J.; Alavi, M.; Sahaboglu, A.; Kustermann, S.; Farinelli, P.; Azadi, S.; Van Veen, T.; Romero, F.J.; Paquet-Durand, F.; Ekström, P. Excessive HDAC activation is critical for neurodegeneration in the rd1 mouse. Cell Death Dis. 2010, 1, e24. [CrossRef] [PubMed]

151. Kawase, R.; Nishimura, Y.; Ashikawa, Y.; Sasagawa, S.; Murakami, S.; Yuge, M.; Okabe, S.; Kawaguchi, K.; Yamamoto, H.; Moriyuki, K.; et al. EP300 Protects from Light-Induced Retinopathy in Zebrafish. Front. Pharmacol. 2016, 7. [CrossRef]

152. Daly, C.; Shine, L.; Heffernan, T.; Deeti, S.; Reynolds, A.L.; O’Connor, J.J.; Dillon, E.T.; Duffy, D.J.; Kolch, W.; Cagney, G.; et al. A Brain-Derived Neurotrophic Factor Mimetic Is Sufficient to Restore Cone Photoreceptor Visual Function in an Inherited Blindness Model. Sci. Rep. 2017, 7, 11320. [CrossRef] [PubMed]

153. Leyk, J.; Daly, C.; Janssen-Bienhold, U.; Kennedy, B.; Richter-Landsberg, C. HDAC6 inhibition by tubastatin A is protective against oxidative stress in a photoreceptor cell line and restores visual function in a zebrafish model of inherited blindness. Cell Death Dis. 2017, 8, e3028. [CrossRef] [PubMed]

154. Sundaramurthi, H.; Roche, S.L.; Grice, G.L.; Moran, A.; Dillion, E.T.; Campiani, G.; Nathan, J.A.; Kennedy, B.N. Selective Histone Deacetylase 6 Inhibitors Restore Cone Photoreceptor Vision or Outer Segment Morphology in Zebrafish and Mouse Models of Retinal Blindness. Front. Cell Dev. Biol. 2020, 8. [CrossRef]

155. Cassar, S.; Adatto, I.; Freeman, J.; Gamse, J.T.; Iturria, I.; Lawrence, C.; Muriana, A.; Peterson, R.T.; Van Cruchten, S.; Zon, L.I. Use of Zebrafish in Drug Discovery Toxicology. Chem. Res. Toxicol. 2020, 33, 95-118. [CrossRef]

156. Deeti, S.; O'Farrell, S.; Kennedy, B.N. Early safety assessment of human oculotoxic drugs using the zebrafish visualmotor response. J. Pharmacol. Toxicol. Methods 2014, 69, 1-8. [CrossRef]

157. Sadamoto, K.; Yamagiwa, Y.; Sakaki, H.; Kurata, M. Absence of histopathological changes in the retina of zebrafish treated with sodium iodate. J. Veter. Med. Sci. 2018, 80, 901-908. [CrossRef] [PubMed]

158. Shi, W.-J.; Huang, G.-Y.; Jiang, Y.-X.; Ma, D.-D.; Chen, H.-X.; Huang, M.-Z.; Hou, L.-P.; Xie, L.; Ying, G.-G. Medroxyprogesterone acetate affects eye growth and the transcription of associated genes in zebrafish. Ecotoxicol. Environ. Saf. 2020, 193, 110371. [CrossRef]

159. Hoshijima, K.; Jurynec, M.J.; Shaw, D.K.; Jacobi, A.M.; Behlke, M.A.; Grunwald, D.J. Highly Efficient CRISPR-Cas9-Based Methods for Generating Deletion Mutations and F0 Embryos that Lack Gene Function in Zebrafish. Dev. Cell 2019, 51, 645-657.e4. [CrossRef] [PubMed] 